\title{
STUDY ON WINES PRODUCED FROM MONOSTROMA NITIDUM HYDROLYSATE SOLUTION
}

\author{
Shao-Chi Wu \\ Department of Food Science and Technology, Tung-Fang Design University, Kaohsiung, Taiwan, R.O.C., \\ agarase@msn.com \\ Fu-Jin Wang \\ Department of Tourism, Aletheia University, Taipei, Taiwan, R.O.C. \\ Jiun-Ru Chen \\ Department of Food Science, National Taiwan Ocean University, Keelung, Taiwan, R.O.C. \\ Chorng-Liang Pan \\ Department of Food Science, National Taiwan Ocean University, Keelung, Taiwan, R.O.C.
}

Follow this and additional works at: https://jmstt.ntou.edu.tw/journal

Part of the Life Sciences Commons

\section{Recommended Citation}

Wu, Shao-Chi; Wang, Fu-Jin; Chen, Jiun-Ru; and Pan, Chorng-Liang (2011) "STUDY ON WINES PRODUCED FROM MONOSTROMA NITIDUM HYDROLYSATE SOLUTION," Journal of Marine Science and Technology: Vol. 19: Iss. 4, Article 13.

DOI: $10.51400 / 2709-6998.2185$

Available at: https://jmstt.ntou.edu.tw/journal/vol19/iss4/13

This Research Article is brought to you for free and open access by Journal of Marine Science and Technology. It has been accepted for inclusion in Journal of Marine Science and Technology by an authorized editor of Journal of Marine Science and Technology. 
STUDY ON WINES PRODUCED FROM MONOSTROMA NITIDUM HYDROLYSATE SOLUTION

Acknowledgements

The authors are grateful to the Fisheries Agency, Council of Agriculture, Executive Yuan, R.O.C., for its support of this work (Grant No. 94 AS-12.1.3-FA-F1-03). 


\title{
STUDY ON WINES PRODUCED FROM MONOSTROMA NITIDUM HYDROLYSATE SOLUTION
}

\author{
Shao-Chi Wu*, Fu-Jin Wang**, Jiun-Ru Chen***, and Chorng-Liang Pan***
}

Key words: agarase, cellulase, Monostroma nitidum, wine.

\section{ABSTRACT}

Two yeast groups, S5: Saccharomyces (S.) cerevisiae BCRC21686 and S. cerevisiae BCRC21962, and S6: S. cerevisiae BCRC21824 and S. cerevisiae BCRC21962, were used to ferment Monostroma (M.) nitidum hydrolysate (MNH) solution under various conditions, such as (1) M. nitidum powder; (2) carbon source; (3) nitrogen source; and (4) yeast group inoculation concentrations, respectively, at $25^{\circ} \mathrm{C}$ in a 10-day M. nitidum wine study. First, the $2.5 \%$ M. nitidum powder particles in the MNH solution elicited better alcohol content than the other concentrations did. Then, the $15 \%$ sucrose and $0.500 \%$ proline in the $\mathrm{MNH}$ solution produced good alcohol content in a carbon source and a nitrogen source, respectively. The S5 and S6 groups also showed improved alcohol content in the yeast group inoculation concentration of $4 \%$. Therefore, we combined these conditions to out carry $M$. nitidum wine fermentation on days $0,5,7,10,14,18$, or 21 . The $M$. nitidum wines with $10 \%, 15 \%$, or $20 \%$ sucrose ferment showed good alcohol and compositional changes after 7, 10, or 14 days, respectively. During the 3 months of aging, the influence on the alcohol content, $\mathrm{pH}$ value, titratable acidity, reducing sugar content and residual sugar content caused by storage temperatures at $15^{\circ} \mathrm{C}$ and $25^{\circ} \mathrm{C}$ on the components of $M$. nitidum wines were not observed. The $M$. nitidum wines aged at $25^{\circ} \mathrm{C}$ showed lower Hunter $\mathrm{L}$, a, and b values than did the $M$. nitidum wines aged at $15^{\circ} \mathrm{C}$. Overall, sensory evaluations showed the best $M$. nitidum wines were fermented with $20 \%$ sucrose added to the $M$. nitidum wine substrate at $25^{\circ} \mathrm{C}$ and then aged at $15^{\circ} \mathrm{C}$ for 3 months. M. nitidum wine can be further studied in the field of $M$. nitidum wine manufacturing.

Paper submitted 02/24/10; revised 07/22/10; 10/03/10; accepted 11/04/10. Author for correspondence: Shao-ChiWu (e-mail: agarase@msn.com). *Department of Food Science and Technology, Tung-Fang Design University, Kaohsiung, Taiwan, R.O.C.

**Department of Tourism, Aletheia University, Taipei, Taiwan, R.O.C.

***Department of Food Science, National Taiwan Ocean University, Keelung, Taiwan, R.O.C.

\section{INTRODUCTION}

The green alga, M. nitidum, has thalli that are foliaceous, soft and gelatinous. It is yellowish green in color, about 2-4.5 $\mathrm{cm}$ tall, 18-33 $\mu$ thick, and is found in Hong Kong, Taiwan, the China Sea, Ryukyu, and Japan. The main component of $M$. nitidum is mucilage, which contains xylose (1.98\%), galactose (19.25\%), galacturonic acid (23.17\%) and rhamnose (52.95\%) [26].

Sulfated polysaccharides from Monostromaceae exhibit many biological activities; they are anticoagulant, antiviral, antiherpetic and antioxidant [48]. Maeda et al. [25] studied heparinoid-active sulfated polysaccharides from $M$. nitridum and found that they were 6-fold more antithrombin-active than the heparin standard. Harada and Maeda [17] analyzed the chemical structure and found it was rhamnan sulfate. The study by Lee et al. [23] of sulfated polysaccharides from $M$. nitidum showed potent anti-Herpes simplex virus type 1 (HSV-1) activity. An M. nitidum diet fed to 30 SpragueDawley rats demonstrated the potential of seaweed as a natural source of sulfated polysaccharide substances with potential for use in chemoprevention medicine [8]. A notable reducing effect of plasma cholesterol in rats was found in the basic fraction of water-extractives; it was able isolate arginine, glycine betaine and $\beta$-homonetaine [1]. Of the two betaines, only $\beta$-homobetaine was able to reduce plasma cholesterol [2]. The water-soluble mucilage of $M$. nitidium showed skin hydration effects which could be useful in the production of cosmetics [9]. Hot water polysaccharide extract and oligosaccharidelysates prepared by two bacterial agarases hydrolyzed, which derived from $M$. nitidium, showed anti-oxidative properties in our previous study [43, 46]. Wu et al. [44] observed that lactic acid bacteria fermented hot water polysaccharide extract and oligosaccharide-lysates prepared by two bacterial agarases which were stepwise hydrolyzed and derived from M. nitidium.

During fermentation in alcoholic beverage production, volatile compounds are produced at various concentrations. These compounds play an important role in the flavour and sensory properties of the alcoholic beverage [37]. Higher alcohols can be classified as aliphatic [n-propanol, isobutanol, 2-methylbutanol (or active amyl alcohol), 3-methyl butanol (or isoamyl alcohol)] or aromatic (2-phenylethanol, tyrosol 
and tryptophol). Aliphatic higher alcohols contribute to the 'alcoholic' or 'solvent' aroma of wine and produce a warm sensation in the mouth. The aromatic alcohol 2-phenylethanol has a sweet aroma, which makes the wine desirable, whereas the aromas of tyrosol and tryptophol are undesirable. Higher alcohols are synthesized by yeast during fermentation via the catabolic (Ehrlich) and anabolic pathways (amino acid metabolism) [42].

$S$. cerevisiae is widely used worldwide in many industries and it is one of the most extensively studied microorganisms [21]. The quality of the wine produced greatly depends on the yeast strain [32]. Conditions which promote yeast cell growth, such as high levels of nutrients (amino acids, oxygen, lipids, zinc), increased temperature and agitation, stimulate the production of higher alcohols. The synthesis of aromatic alcohols is especially sensitive to temperature changes. On the other hand, conditions which restrict yeast growth, such as lower temperature and higher $\left(\mathrm{CO}_{2}\right)$ pressure, can reduce the extent of higher alcohol production. The amino acid composition has a major effect on higher alcohol formation: growth medium supplemented with valine, isoleucine and leucine induced the formation of isobutanol, amyl alcohol and isoamyl alcohol, respectively [42].

Many researchers have studied alcoholic beverages employing yeast from different raw materials: sugar beets, wheat, maize, potatoes, sugar cane, and sweet sorghum are rich in single sugars or polymers which are easy to hydrolyze [33]. This work deals with wine prepared from $M$. nitidium and the compositional changes during fermentation and aging.

\section{MATERIALS AND METHODS}

\section{Strains}

\section{1) Agarases-Producing Strains}

Agarases-producing strains, Aeromonas (A.) salmonicida MAEF108 with agar-softening isolated from the seawater off the coast at Keelung in Taiwan [43-46].

\section{2) Wine-Producing Strains}

S. cerevisiae BCRC21686, BCRC21824, and BCRC21962, obtained from the Bioresources Collection and Research Center (BCRC), Food Industry Research and Development Institute (FIRDI), Hsinchu, Taiwan, were tested for alcohol fermentation using $M$. nitidum.

\section{Monostroma nitidum Powder Particles}

M. nitidum was purchased from a traditional market in Penghu, Taiwan. The proximate composition of ash, carbohydrate, crude fiber, crude lipid, crude protein, and moisture were prepared according to the methods described in AOAC [4]. The dried $M$. nitidum alga was crushed, and then screened by means of a standard screening sieve (Tokyo Garasu KiKai Co. Ltd, Tokyo, Japan), so the M. nitidum powder particles were smaller than $0.42 \mathrm{~mm}[43,46]$.

\section{Preparation of $M$. nitidum Hydrolysate Solution}

\section{1) Types of Digestive Enzyme}

The commercial enzyme cellulase was purchased from Challenge Bioproducts Co. Ltd, Yunlin, Taiwan. The preparation of crude enzyme solution of MAEF108-agarases was prepared according to the method of previous studies [43, 46], and the assay of agarase activity was carried out in accordance with the same references.

\section{2) M. nitidum Hydrolysate Solution}

The hydrolysate solution of $M$. nitidum was obtained by a modified method described in previous studies [43, 46]. First, $M$. nitidum powder particles of $2.5 \% \mathrm{M}$. nitidum were suspended in $300 \mathrm{~mL}$ of deionized water and heated at $90^{\circ} \mathrm{C}$ for $10 \mathrm{~min}$. The $M$. nitidum solution cooled to $40^{\circ} \mathrm{C}$ with the $\mathrm{pH}$ value adjusted to 5.5 by lactic acid (Panreac, Monteada $\mathrm{i}$ Reixac, Barcelona, Spain) is referred to as the $\mathrm{MN}$ (M. nitidum) solution. Then, 10 unit/mL MAEF108-agarases and 10 unit $/ \mathrm{mL}$ cellulase were added to the MN solution which was placed at $40^{\circ} \mathrm{C}$. Then, enzyme digestion was carried out for $6 \mathrm{~h}$. After digestion, the $\mathrm{MN}$ solution containing $2.5 \% \mathrm{M}$. nitidum powder particles digested by 10 units/mL MAEF-108 agarases and 10 units $/ \mathrm{mL}$ cellulase is referred to as $\mathrm{MNH}$ (M. nitidum hydrolysate) solution.

\section{Fermentation Conditions of $M$. nitidum Wine}

\section{1) M. nitidum Wine-Producing Starter Groups}

Our pervious study showed that the $M$. nitidum wine-producing starter groups that obtained the highest alcohol content: S5: BCRC21686 + BCRC21962 and S6: BCRC21824+ BCRC21962, were used as M. nitidum wine-producing starters in this study. The duration of the fermentation time was 10 days at $25^{\circ} \mathrm{C}$, and the microbiological composition of the $M$. nitidum wine were determined as describe in exp. 6 .

\section{2) Carbon Source}

Three hundred $\mathrm{mL}$ of $\mathrm{MNH}$ solution had $15 \%$ glucose, maltose or sucrose added in order to choose the best carbon source. The duration of the fermentation time and the microbiological composition of the $M$. nitidum wine were determined in the same way as in exp. 4-1.

\section{3) Nitrogen Source}

Three hundred $\mathrm{mL}$ of $\mathrm{MNH}$ solution containing $15 \%$ sucrose was added to $0.125 \%-1.000 \% \mathrm{NH}_{4} \mathrm{Cl}, \mathrm{NH}_{4} \mathrm{H}_{2} \mathrm{PO}_{4}$, or proline to choose the best nitrogen source. The duration of the fermentation time and the microbiological composition of the M. nitidum wine were determined in the same way as in exp. 4-1.

\section{4) Inoculated Concentration of M. nitidum Wine-Producing Starter Groups}

M. nitidum wine-producing starter groups were added in amounts of $2 \%, 4 \%, 6 \%, 8 \%$, or $10 \%$ to choose the best in- 
oculated concentration. The duration of the fermentation time and the microbiological composition of the M. nitidum wine were determined in the same way as in exp. 4-1.

\section{5) Fermentation Time of M. nitidum Wine Producing Starter Groups}

According to the results of Experiments 4-2, 4-3, and 4-4, the carbon source, nitrogen source, and inoculated concentration which exhibited the highest alcohol content were selected. The fermentation times of the $M$. nitidum wine-producing starter groups were $0,5,7,10,14,18$, or 21 days. The duration of the fermentation time and the microbiological and composition of the M. nitidum wine were determined in the same way as in exp. 4-1.

\section{Aging of $M$. nitidum Wine}

The aging of $M$. nitidum wine prepared from the $\mathrm{MNH}$ solution containing $2.5 \% \mathrm{M}$. nitidum powder particles, $0.5 \%$ proline, and $10 \%-20 \%$ sucrose was fermented by inoculation with 4\% yeast groups S5: BCRC21686 + BCRC21962 and S6: BCRC21824 + BCRC21962 at 15 or $25^{\circ} \mathrm{C}$, respectively. The duration of the aging was 3 months and the microbiological and chemical composition of the M. nitidum wine was determined in the same way as in exp. 4-1 every 2 weeks.

\section{Microbiological and Chemical Analyses}

\section{1) Determination of Acidity}

The $\mathrm{pH}$ levels of the $M$. nitidum wine samples were measured at room temperature $\left(23\right.$ to $\left.25^{\circ} \mathrm{C}\right)$ using a $\mathrm{pH}$ meter (MP220, Mettler Toledo, Schwerzenbach, Switzerland) (triplicatelly) after calibration with fresh $\mathrm{pH} 4.0$ and 7.0 standard buffers (Panreac) [44, 45].

\section{2) Determination of Titratable Acidity (TA)}

TA was determined by the AOAC method and expressed as $\%$ tartaric acid [4].

\section{3) Determination of Alcohol Content}

Fifty milliliter M. nitidum wine samples were placed in 250 $\mathrm{mL}$ distilling flasks and then loaded into a Soxtec manual extraction unit (Model 2058, Foss Tecator, Sweden) for distillated alcohol. After the distillated alcohol reached $45 \mathrm{~mL}$, $50 \mathrm{~mL}$ of deionized water was added and mixed well. Finally, an alcohol hydrometer measured the alcohol content expressed as $\%(\mathrm{v} / \mathrm{v})[35]$.

\section{4) Determination of Reducing Sugar Content}

The dinitro salicylic acid method of Miller et al. [28] was used to estimate reducing sugar. One milliliter of the $M$. nitidum wine was reacted with an alkaline solution of 3,5-dinitrosalicylate reagent to give the brown-colored 3-amino5-nitrosalicylic acid solution. Extinction was measured at 540 $\mathrm{nm}$. The quantity of reducing sugar was extrapolated from a calibration curve prepared with D-glucose.

\section{5) Determination of Total Sugar Content}

Total sugar content was measured by the phenol-sulphuricacid method using glucose as the standard [13].

\section{6) Determination of Residual Sugar Content}

The residual sugar content was determined following the method of Amerine and Ough [3].

\section{7) Determination of $S$. cerevisiae Count}

YM agar was used for the enumeration of $M$. nitidum alcohol-producing starters. One milliliter of each sample was diluted with $9 \mathrm{~mL}$ of sterilized $0.85 \%$ (w/v) $\mathrm{NaCl}$ (Panreac) solution and vortex thoroughly. Subsequent serial dilutions were prepared, and viable numbers were enumerated using the spread-plated technique onto the YM agar. After $48 \mathrm{~h}$ of incubation at $25^{\circ} \mathrm{C}$, the colonies appearing on the plates were counted and the $\mathrm{CFU} / \mathrm{mL}$ was calculated [15].

\section{8) Determination of Hunter $L, a$, and $b$ values}

Samples of M. nitidum wine were centrifuged at 5,000 $\times \mathrm{g}$ at $4^{\circ} \mathrm{C}$ for $10 \mathrm{~min}$, and the supernatant was collected. Visual color was measured using a Hunter color meter (Model TC-10 Analyzer, Denshoku Co., Tokyo, Japan) and was expressed as L, a, or b (brightness, redness and yellowness, respectively) [7].

\section{Sensory Evaluation for M. nitidum Wines}

The sensory evaluation and aging of all $M$. nitidum wines were initially studied on the basis of a 9-point hedonic scale test $(1=$ dislike extremely; $3=$ dislike; $5=$ neither like nor dislike; 7 = like; $9=$ like extremely), and used to evaluate sensory attributes for color, flavor, taste, or overall preference.

\section{Statistical Analysis}

All results from testing the acidity, TA, alcohol content, reducing sugar content, total sugar content, residual sugar content, $S$. cerevisiae count, and Hunter L, a, b values of the $M$. nitidum wine are expressed as mean $\pm \mathrm{SD}(\mathrm{n}=3)$. Results from the sensory evaluation of $M$. nitidum wines are expressed as mean $\pm \mathrm{SD}(\mathrm{n}=16)$. Results from the sensory evaluation aging of $M$. nitidum wines are expressed as mean \pm SD $(\mathrm{n}=$ 20). Data were analyzed by a one-way analysis of variance (ANOVA). When the ANOVA identified differences between the groups, multiple comparisons of the means were made using Duncan's new multiple range tests. Statistical significance was determined by setting the aggregate type I error at $5 \%(p<0.05)$ for each set of comparisons, using the Statistical Analysis System software package [36].

\section{RESULTS AND DISCUSSION}

\section{Concentrations of M. nitidum Powder Particles in MNH Solution}

Table 1 shows the analyses of yeast count, alcohol content, $\mathrm{pH}$ value, TA, reducing sugar content, and residual sugar con- 
Table 1. The analyses of the yeast count, alcohol content, $\mathrm{pH}$ value, titratable acidity, reducing sugar content, and residual sugar content of $0.5 \%-3.0 \% \mathrm{M}$. nitidum hydrolysate solution with $15 \%$ sucrose added that fermented at $25^{\circ} \mathrm{C}$ for 10 days.

\begin{tabular}{cccccccc}
\hline Groups $^{1}$ & $\begin{array}{c}\text { M. nitidum } \\
\text { powder }(\%)\end{array}$ & $\begin{array}{c}\text { Yeast count } \\
(\text { Log CFU/mL) }\end{array}$ & $\begin{array}{c}\text { Alcohol content } \\
(\%, \mathrm{v} / \mathrm{v})\end{array}$ & $\mathrm{pH}^{\mathrm{d} \text { value }}$ & $\begin{array}{c}\text { Titratable acidity } \\
(\%)\end{array}$ & $\begin{array}{c}\text { Reducing sugar } \\
(\%)\end{array}$ & $\begin{array}{c}\text { Residual sugar } \\
\left({ }^{\mathrm{o}} \text { Brix }\right)\end{array}$ \\
\hline \multirow{6}{*}{ S5 } & 0.5 & $7.10 \pm 0.10^{\mathrm{c} 2}$ & $5.45 \pm 0.10^{\mathrm{d}}$ & $3.79 \pm 0.27^{\mathrm{f}}$ & $0.06 \pm 0.01^{\mathrm{d}}$ & $2.84 \pm 0.03^{\mathrm{a}}$ & $3.63 \pm 0.06^{\mathrm{e}}$ \\
& 1.0 & $7.42 \pm 0.06^{\mathrm{a}}$ & $6.88 \pm 0.17^{\mathrm{ab}}$ & $3.86 \pm 0.23^{\mathrm{e}}$ & $0.08 \pm 0.00^{\mathrm{c}}$ & $0.42 \pm 0.02^{\mathrm{b}}$ & $4.06 \pm 0.03^{\mathrm{d}}$ \\
& 1.5 & $7.40 \pm 0.05^{\mathrm{a}}$ & $6.71 \pm 0.20^{\mathrm{bc}}$ & $3.92 \pm 0.00^{\mathrm{d}}$ & $0.09 \pm 0.00^{\mathrm{c}}$ & $0.37 \pm 0.00^{\mathrm{c}}$ & $4.20 \pm 0.00^{\mathrm{c}}$ \\
& 2.0 & $7.35 \pm 0.04^{\mathrm{ab}}$ & $6.85 \pm 0.34^{\mathrm{ab}}$ & $3.95 \pm 0.35^{\mathrm{c}}$ & $0.11 \pm 0.01^{\mathrm{b}}$ & $0.39 \pm 0.01^{\mathrm{bc}}$ & $4.30 \pm 0.00^{\mathrm{c}}$ \\
& 2.5 & $7.37 \pm 0.00^{\mathrm{ab}}$ & $7.25 \pm 0.12^{\mathrm{a}}$ & $4.03 \pm 0.21^{\mathrm{b}}$ & $0.12 \pm 0.00^{\mathrm{b}}$ & $0.35 \pm 0.04^{\mathrm{c}}$ & $4.60 \pm 0.10^{\mathrm{b}}$ \\
& 3.0 & $7.01 \pm 0.12^{\mathrm{c}}$ & $6.68 \pm 0.56^{\mathrm{c}}$ & $4.10 \pm 0.35^{\mathrm{a}}$ & $0.16 \pm 0.01^{\mathrm{a}}$ & $0.37 \pm 0.01^{\mathrm{c}}$ & $4.86 \pm 0.03^{\mathrm{a}}$ \\
\hline \multirow{6}{*}{$\mathrm{S} 6$} & 0.5 & $6.97 \pm 0.20^{\mathrm{a}}$ & $4.94 \pm 0.30^{\mathrm{e}}$ & $3.73 \pm 0.01^{\mathrm{e}}$ & $0.05 \pm 0.00^{\mathrm{d}}$ & $3.25 \pm 0.02^{\mathrm{a}}$ & $6.17 \pm 0.06^{\mathrm{a}}$ \\
& 1.0 & $6.96 \pm 0.01^{\mathrm{a}}$ & $6.84 \pm 0.09^{\mathrm{bc}}$ & $3.81 \pm 0.01^{\mathrm{d}}$ & $0.06 \pm 0.01^{\mathrm{d}}$ & $0.51 \pm 0.00^{\mathrm{c}}$ & $4.20 \pm 0.03^{\mathrm{e}}$ \\
& 1.5 & $6.89 \pm 0.15^{\mathrm{a}}$ & $6.90 \pm 0.21^{\mathrm{ab}}$ & $3.83 \pm 0.02^{\mathrm{d}}$ & $0.08 \pm 0.01^{\mathrm{c}}$ & $0.41 \pm 0.04^{\mathrm{d}}$ & $4.30 \pm 0.00^{\mathrm{d}}$ \\
& 2.0 & $6.81 \pm 0.06^{\mathrm{a}}$ & $6.62 \pm 0.10^{\mathrm{c}}$ & $3.87 \pm 0.02^{\mathrm{c}}$ & $0.09 \pm 0.01^{\mathrm{c}}$ & $0.36 \pm 0.01^{\mathrm{e}}$ & $4.33 \pm 0.06^{\mathrm{d}}$ \\
& 2.5 & $6.73 \pm 0.10^{\mathrm{a}}$ & $7.13 \pm 0.26^{\mathrm{a}}$ & $3.95 \pm 0.00^{\mathrm{b}}$ & $0.11 \pm 0.00^{\mathrm{b}}$ & $0.45 \pm 0.00^{\mathrm{d}}$ & $4.50 \pm 0.00^{\mathrm{c}}$ \\
& 3.0 & $6.14 \pm 0.25^{\mathrm{b}}$ & $6.80 \pm 0.20^{\mathrm{bc}}$ & $4.02 \pm 0.01^{\mathrm{a}}$ & $0.14 \pm 0.00^{\mathrm{a}}$ & $0.90 \pm 0.05^{\mathrm{b}}$ & $4.76 \pm 0.03^{\mathrm{b}}$ \\
\hline
\end{tabular}

${ }^{1}$ : S5: M. nitidum hydrolysate solution + 15\% sucrose fermented by S. cerevisiae BCRC21686 (2.5\%) and BCRC21962 (2.5\%); S6: M. nitidum hydrolysate solution $+15 \%$ sucrose fermented by S. cerevisiae BCRC21824 (2.5\%) and BCRC21962 (2.5\%).

2: Each value is the means \pm standard deviation $(\mathrm{n}=3)$ and the different superscript letters in the same column are significantly different $(p<$ $0.05)$.

tent of $0.5 \%-3.0 \%$ M. nitidum hydrolysate solution, with $15 \%$ sucrose added, fermented at $25^{\circ} \mathrm{C}$ for 10 days. The yeast count, alcohol content, $\mathrm{pH}$ value, TA, reducing sugar content, and residual sugar content were 7.01-7.42 $\log \mathrm{CFU} / \mathrm{mL}, 5.45-$ $7.25 \%, 3.79-4.10,0.06-0.16 \%, 0.35-2.84 \%$, and $3.63-4.86$ ${ }^{\circ}$ Brix, respectively, for the S5 yeast group fermented with different $M$. nitidum powder particles concentrations; and 6.14-6.97 log CFU/mL, 4.94-7.13\%, 3.73-4.02, 0.05-0.14\%, 0.36-3.25\%, and $4.20-6.17^{\circ}$ Brix, respectively, for the S6 yeast group fermented with different $M$. nitidum powder particle concentrations. The highest alcohol contents of the S5 and S6 yeast groups were $7.25 \%$ and $7.13 \%$, respectively, and both occurred with $2.5 \% \mathrm{M}$. nitidum powder particles in the $\mathrm{MNH}$ solution. The increase in alcohol content with the concentration in MNH solution could be due to the formation of simple sugar by the enzyme hydrolyzed polysaccharide in M. nitidum. In our previous study, the reducing sugar content increased with $M$. nitidum powder particle concentrations from 0.5 to $3.0 \%$ in $\mathrm{MNH}$ solution, attesting to this phenomenon.

In many types of cells, osmotic stress interferes with cell volume and intracellular inorganic ion homeostasis. Most cells shrink when exposed to hyperosmotic medium and swell in hypo-osmotic medium as a result of osmosis. The resulting change in cell volume is accompanied by an alteration in the intracellular density of macromolecules. Osmotic stress may damage cellular macromolecules and impair cell function until compensatory adaptations counteract the stress. Damage to DNA and proteins leads to impairment of cell function and to the induction of repair processes and protection systems [22]. Moreover, high osmotic pressure, the formation of elevated levels of toxic fermentation by-products (such as ethanol), and limiting yeast nutritional factors have been implicated as key factors contributing to the deleterious results in yeast fermentation [20]. The fermentation of high sugar grape musts can occur in winemaking for wine production from dried, botrytized or late-harvest grapes, for ice-wine production or in processing industries that use grape juice concentrate. When using musts with high sugar concentrations, stuck or sluggish fermentations are probable because of the high osmotic pressure and ethanol toxicity of yeast cells [27]. Therefore, in accordance with the research results of Chiang et al. [10] on the conversion of D-xylulose to ethanol in the presence of $\mathrm{D}$-xylose, the rate of ethanol production increased with an increase in yeast cell density. The rate of D-xylulose fermentation decreased when the production of ethanol yielded concentrations of $4 \%$ or more. The slow conversion rate of D-xylulose to ethanol was increased by increasing the yeast cell density. In the study by D'Amore et al. [12] on the intracellular accumulation of ethanol in $S$. cerevisiae, fermentation was observed after $3 \mathrm{~h}$. After $12 \mathrm{~h}$ of fermentation, the intracellular and extracellular ethanol concentrations were similar. Increasing the osmotic pressure of the medium caused an increase in the ratio of intracellular to extracellular ethanol concentrations at $3 \mathrm{~h}$ of fermentation. Increasing the osmotic pressure caused a decrease in yeast cell growth and fermentation activities. D'Amore et al. [12] suggested that nutrient limitation was a major factor responsible for the decreased growth and fermentation activities observed in yeast cells at higher osmotic pressures.

\section{Carbon Source}

The most efficient sugar-fermenting yeast, $S$. cerevisiae (fermentable substrates such as glucose or fructose that convert into alcohol and $\mathrm{CO}_{2}$ ) are metabolized more easily than 
Table 2. The analyses of the yeast count, alcohol content, $\mathbf{p H}$ value, titratable acidity, reducing sugar content, and residual sugar content of $2.5 \% \mathrm{M}$. nitidum hydrolysate solution with $15 \%$ different types of sugars added that fermented at $25^{\circ} \mathrm{C}$ for 10 days.

\begin{tabular}{ccccccrr}
\hline \multirow{2}{*}{ Groups $^{1}$} & Sugars & $\begin{array}{c}\text { Yeast count } \\
(\text { Log CFU/mL) }\end{array}$ & $\begin{array}{c}\text { Alcohol content } \\
(\%, \mathrm{v} / \mathrm{v})\end{array}$ & pH value & $\begin{array}{c}\text { Titratable acidity } \\
(\%)\end{array}$ & $\begin{array}{c}\text { Reducing sugar } \\
(\%)\end{array}$ & $\begin{array}{c}\text { Residual sugar } \\
\left({ }^{\circ} B r i x\right)\end{array}$ \\
\hline \multirow{3}{*}{ S5 } & Glucose & $6.88 \pm 0.00^{\mathrm{cd} 2}$ & $6.10 \pm 0.21^{\mathrm{b}}$ & $4.02 \pm 0.04^{\mathrm{c}}$ & $0.17 \pm 0.02^{\mathrm{a}}$ & $0.16 \pm 0.02^{\mathrm{e}}$ & $4.03 \pm 0.06^{\mathrm{f}}$ \\
& Maltose & $7.33 \pm 0.15^{\mathrm{b}}$ & $3.71 \pm 0.35^{\mathrm{c}}$ & $4.07 \pm 0.01^{\mathrm{a}}$ & $0.18 \pm 0.01^{\mathrm{a}}$ & $8.91 \pm 0.01^{\mathrm{b}}$ & $9.80 \pm 0.00^{\mathrm{b}}$ \\
& Sucrose & $7.86 \pm 0.10^{\mathrm{a}}$ & $7.17 \pm 0.18^{\mathrm{a}}$ & $4.08 \pm 0.09^{\mathrm{bc}}$ & $0.12 \pm 0.01^{\mathrm{b}}$ & $0.39 \pm 0.07^{\mathrm{d}}$ & $4.10 \pm 0.00^{\mathrm{e}}$ \\
\hline \multirow{2}{*}{$\mathrm{S} 6$} & Glucose & $6.91 \pm 0.06^{\mathrm{c}}$ & $3.71 \pm 0.31^{\mathrm{c}}$ & $4.06 \pm 0.01^{\mathrm{ab}}$ & $0.18 \pm 0.00^{\mathrm{a}}$ & $0.17 \pm 0.01^{\mathrm{e}}$ & $4.66 \pm 0.03^{\mathrm{c}}$ \\
& Maltose & $6.75 \pm 0.12^{\mathrm{d}}$ & $1.91 \pm 0.11^{\mathrm{d}}$ & $4.05 \pm 0.00^{\mathrm{abc}}$ & $0.19 \pm 0.01^{\mathrm{a}}$ & $11.05 \pm 0.03^{\mathrm{a}}$ & $10.70 \pm 0.00^{\mathrm{a}}$ \\
& Sucrose & $7.23 \pm 0.15^{\mathrm{b}}$ & $7.10 \pm 0.16^{\mathrm{a}}$ & $3.99 \pm 0.02^{\mathrm{d}}$ & $0.11 \pm 0.01^{\mathrm{b}}$ & $0.48 \pm 0.05^{\mathrm{c}}$ & $4.56 \pm 0.03^{\mathrm{d}}$ \\
\hline
\end{tabular}

${ }^{1}$ : S5: M. nitidum hydrolysate solution + 15\% sucrose fermented by S. cerevisiae BCRC21686 (2.5\%) and BCRC21962 (2.5\%); S6: M. nitidum hydrolysate solution $+15 \%$ sucrose fermented by S. cerevisiae BCRC21824 (2.5\%) and BCRC21962 (2.5\%).

${ }^{2}$ : Each value is the means \pm standard deviation $(n=3)$ and the different superscript letters in the same column are significantly different $(p<$ $0.05)$.

alternative sugars like maltose, galactose, sucrose etc. [6] This type of yeast requires the addition of carbon sources for $S$. cerevisiae fermented wines to reach ideal alcohol content when reducing sugar is lacking in raw materials. Therefore, in the $M$. nitidum wine from the MNH solution that was fermented by $S$. cerevisiae a carbon source, glucose, maltose, or sucrose were used as the energy sources for the test. The analyses of the yeast count, alcohol content, $\mathrm{pH}$ value, TA, reducing sugar content, and residual sugar content of the $2.5 \% \mathrm{MNH}$ solution, with $15 \%$ of different types of sugars added and fermentation at $25^{\circ} \mathrm{C}$ for 10 days, are shown in Table 2. The yeast count, alcohol content, $\mathrm{pH}$ value, TA, reducing sugar content, and residual sugar content were 6.88-7.86 log CFU/mL, 3.71-7.17\%, 4.02-4.08, 0.12-0.18\%, $0.16-8.91 \%$, and $4.10-9.80{ }^{\circ}$ Brix, respectively, for the S5 yeast group with different sugar types; and 6.75-7.23 log $\mathrm{CFU} / \mathrm{mL}, 1.91-7.10 \%$, 3.99-4.06, 0.11-0.19\%, 0.17-11.05\%, and 4.56-10.70 ${ }^{\circ} \mathrm{Brix}$, respectively, for the S6 yeast group with different sugar types. The highest alcohol contents of the S5 or S6 yeast groups were $7.17 \%$ and $7.10 \%$, respectively, and both occurred in $2.5 \% \mathrm{M}$. nitidum powder particles in MNH solution with $15 \%$ sucrose. The trend of the carbohydrates used by yeast in $M$. nitidum wines was sucrose $>$ glucose $>$ maltose. In compliance with the results of $S$. cerevisiae, sucrose was used as the carbon source for producing alcohol rather than the other sugars in later M. nitidum wine fermentation experiments.

Using sucrose as the carbon source, $S$. cerevisiae produced higher ethanol content than when using glucose or maltose. During wine fermentation, yeasts convert most of the glucose and fructose present into alcohol and $\mathrm{CO}_{2}$ [16]. Depending on the type of wine being produced, all the sugar may be fermented into alcohol to produce a dry wine [11]. The disaccharides used in this study can easily be accepted as nutrients, by breaking maltose down into two glucoses, and sucrose hydrolyzed by invertase to form glucose and fructose. Grape musts contain equal amounts of glucose and fructose, and the $S$. cerevisiae is glucophilic yeast which prefers glucose to fructose. During the fermentation period, glucose is fermented at a higher rate than fructose, and the proportion of fructose therefore increases as fermentation progresses. Consequently, fructose becomes the main sugar present during the late stages of alcoholic fermentation, and wine yeasts have to ferment this nonpreferred sugar after long periods of starvation and in the presence of large amounts of ethanol [19]. Phowchinda and Strehaiano [33] observed that the hydrolysis of sucrose by $S$. cerevisiae takes place very early during fermentation, and the glucose level is lower than the fructose level, confirming the faster use of glucose. In fact, sucrose is hydrolyzed faster when the glucose is exhausted. Finally, by the end of fermentation, it seems that a stationary phase was reached. The sugar consumption rate equaled the hydrolysis rate and no glucose or fructose accumulation was noticed during this phase.

Houghton-Larsen and Brandt [18] indicated that maltose metabolism in $S$. cerevisiae was negatively regulated by glucose at both the transcriptional level and at the enzyme activity level. Despite this multilayered regulation of maltose metabolism, $S$. cerevisiae cells can have difficulties in coping with sudden changes in extracellular maltose concentration. Exposure of aerobic, maltose-limited chemostat cultures, to excess maltose has even reportedly resulted in maltose-accelerated death. This loss of viability, which was accompanied by the release of glucose in the medium, was interpreted to be a result of non-restricted maltose uptake and hydrolysis, with the resulting accumulation of glucose and protons in the cells leading to cell death and lysis. Release of glucose upon exposure to excess maltose was also observed in $S$. cerevisiae mutants that were defective in glucose catabolite repression [19]. Therefore, the alcohol content of sucrose in the MNH solution fermented by $S$. cerevisiae was higher than that with maltose as the carbon source.

\section{Nitrogen Source}

During ethanol fermentation, yeast must adapt rapidly to the rich environment using the available nitrogen for the 
Table 3. The analyses of the yeast count, alcohol content, $\mathrm{pH}$ value, titratable acidity, reducing sugar content, and residual sugar content of $2.5 \% \mathrm{M}$. nitidum hydrolysate solution with various contents of ammonium dihydrogen phosphate $\left(\mathrm{NH}_{4} \mathrm{H}_{2} \mathrm{PO}_{4}\right)$ added that fermented at $25^{\circ} \mathrm{C}$ for 10 days.

\begin{tabular}{cccccccc}
\hline Groups $^{1}$ & $\begin{array}{c}\mathrm{NH}_{4} \mathrm{H}_{2} \mathrm{PO}_{4} \\
(\%)\end{array}$ & $\begin{array}{c}\text { Yeast count } \\
(\text { Log CFU/mL) }\end{array}$ & $\begin{array}{c}\text { Alcohol content } \\
(\%, \mathrm{v} / \mathrm{v})\end{array}$ & pH value & $\begin{array}{c}\text { Titratable acidity } \\
(\%)\end{array}$ & $\begin{array}{c}\text { Reducing sugar } \\
(\%)\end{array}$ & $\begin{array}{c}\text { Residual sugar } \\
\left({ }^{\circ} B r i x\right)\end{array}$ \\
\hline \multirow{6}{*}{$\mathrm{S} 5$} & 0.000 & $7.30 \pm 0.12^{\mathrm{a} 2}$ & $7.22 \pm 0.12^{\mathrm{bc}}$ & $4.03 \pm 0.02^{\mathrm{bcd}}$ & $0.12 \pm 0.00^{\mathrm{d}}$ & $0.35 \pm 0.04^{\mathrm{c}}$ & $4.60 \pm 0.00^{\mathrm{bc}}$ \\
& 0.125 & $7.24 \pm 0.21^{\mathrm{a}}$ & $7.26 \pm 0.25^{\mathrm{bc}}$ & $4.09 \pm 0.01^{\mathrm{abc}}$ & $0.15 \pm 0.01^{\mathrm{c}}$ & $0.30 \pm 0.01^{\mathrm{d}}$ & $4.76 \pm 0.03^{\mathrm{ab}}$ \\
& 0.250 & $7.15 \pm 0.11^{\mathrm{a}}$ & $7.29 \pm 0.13^{\mathrm{bc}}$ & $4.15 \pm 0.02^{\mathrm{ab}}$ & $0.15 \pm 0.01^{\mathrm{c}}$ & $0.27 \pm 0.02^{\mathrm{e}}$ & $4.80 \pm 0.00^{\mathrm{a}}$ \\
& 0.500 & $7.11 \pm 0.05^{\mathrm{ab}}$ & $7.43 \pm 0.18^{\mathrm{ab}}$ & $4.18 \pm 0.00^{\mathrm{a}}$ & $0.19 \pm 0.02^{\mathrm{a}}$ & $0.31 \pm 0.01^{\mathrm{d}}$ & $4.80 \pm 0.00^{\mathrm{a}}$ \\
& 1.000 & $6.94 \pm 0.20^{\mathrm{b}}$ & $6.92 \pm 0.19^{\mathrm{d}}$ & $3.90 \pm 0.02^{\mathrm{ef}}$ & $0.17 \pm 0.00^{\mathrm{b}}$ & $0.33 \pm 0.00^{\mathrm{cd}}$ & $4.70 \pm 0.00^{\mathrm{ab}}$ \\
\hline \multirow{6}{*}{$\mathrm{S} 6$} & 0.000 & $6.72 \pm 0.06^{\mathrm{c}}$ & $7.13 \pm 0.17^{\mathrm{c}}$ & $3.95 \pm 0.00^{\mathrm{def}}$ & $0.11 \pm 0.00^{\mathrm{d}}$ & $0.45 \pm 0.00^{\mathrm{a}}$ & $4.53 \pm 0.06^{\mathrm{c}}$ \\
& 0.125 & $6.70 \pm 0.10^{\mathrm{c}}$ & $7.24 \pm 0.12^{\mathrm{bc}}$ & $4.08 \pm 0.01^{\mathrm{abc}}$ & $0.14 \pm 0.01^{\mathrm{c}}$ & $0.39 \pm 0.02^{\mathrm{b}}$ & $4.40 \pm 0.00^{\mathrm{d}}$ \\
& 0.250 & $6.63 \pm 0.05^{\mathrm{c}}$ & $7.50 \pm 0.26^{\mathrm{a}}$ & $4.06 \pm 0.02^{\mathrm{abcd}}$ & $0.17 \pm 0.00^{\mathrm{b}}$ & $0.43 \pm 0.00^{\mathrm{a}}$ & $4.56 \pm 0.03^{\mathrm{c}}$ \\
& 0.500 & $6.62 \pm 0.06^{\mathrm{c}}$ & $7.16 \pm 0.20^{\mathrm{c}}$ & $4.02 \pm 0.00^{\mathrm{cde}}$ & $0.18 \pm 0.00^{\mathrm{ab}}$ & $0.45 \pm 0.02^{\mathrm{a}}$ & $4.40 \pm 0.00^{\mathrm{bc}}$ \\
& 1.000 & $6.24 \pm 0.13^{\mathrm{d}}$ & $6.89 \pm 0.21^{\mathrm{d}}$ & $3.84 \pm 0.01^{\mathrm{f}}$ & $0.17 \pm 0.01^{\mathrm{b}}$ & $0.45 \pm 0.01^{\mathrm{a}}$ & $4.50 \pm 0.00^{\mathrm{ab}}$ \\
\hline
\end{tabular}

${ }^{1}$ : S5: M. nitidum hydrolysate solution $+15 \%$ sucrose fermented by S. cerevisiae BCRC21686 (2.5\%) and BCRC21962 (2.5\%); S6: M. nitidum hydrolysate solution $+15 \%$ sucrose fermented by S. cerevisiae BCRC21824 (2.5\%) and BCRC21962 (2.5\%).

2: Each value is the means \pm standard deviation $(\mathrm{n}=3)$ and the different superscript letters in the same column are significantly different $(p<$ $0.05)$.

synthesis of cellular proteins and other cell compounds [24]. Tables 3 to 5 show the results of the addition of different nitrogen sources to MNH solution fermented by $S$. cerevisiae. Table 3 shows the analyses of the yeast count, alcohol content, $\mathrm{pH}$ value, TA, reducing sugar content, and residual sugar content of the $2.5 \% \mathrm{MNH}$ solution with various concentrations of ammonium dihydrogen phosphate $\left(\mathrm{NH}_{4} \mathrm{H}_{2} \mathrm{PO}_{4}\right)$ added with fermentation at $25^{\circ} \mathrm{C}$ for 10 days. The yeast count, alcohol content, $\mathrm{pH}$ value, TA, reducing sugar content, and residual sugar content were 6.94-7.30 $\log \mathrm{CFU} / \mathrm{mL}$, 6.92$7.43 \%, 3.90-4.18,0.12-0.19 \%, 0.27-0.35 \%, 4.6-4.8{ }^{\circ} \mathrm{Brix}$, respectively, for the $\mathrm{S} 5$ yeast group with different $\mathrm{NH}_{4} \mathrm{H}_{2} \mathrm{PO}_{4}$ concentrations; and 6.24-6.72 log CFU/mL, 6.89-7.50\%, $3.84-48,0.11-0.18 \%, 0.39-0.45 \%$, and $4.40-4.56$ Brix, respectively, for the S6 yeast group with different $\mathrm{NH}_{4} \mathrm{H}_{2} \mathrm{PO}_{4}$ concentrations. The highest alcohol contents of the S5 or the S6 yeast group were $7.43 \%$ or $7.50 \%$, respectively, occurring with $2.5 \%$ M. nitidum powder particles in $\mathrm{MNH}$ solution with $0.500 \%$ or $0.250 \% \mathrm{NH}_{4} \mathrm{H}_{2} \mathrm{PO}_{4}$.

The analyses of the yeast count, alcohol content, $\mathrm{pH}$ value, TA, reducing sugar content, and residual sugar content of the $2.5 \% \mathrm{MNH}$ solution with various amounts of ammonium chloride $\left(\mathrm{NH}_{4} \mathrm{Cl}\right)$ added with fermentation at $25^{\circ} \mathrm{C}$ for 10 days are shown in Table 4 . The yeast count, alcohol content, $\mathrm{pH}$ value, TA, reducing sugar content, and residual sugar content were 7.15-7.43 $\log \mathrm{CFU} / \mathrm{mL}, 7.01-7.50 \%, 3.61-4.03,0.12-$ $0.18 \%, 0.32-0.41 \%$, and $4.50-4.60$ Brix, respectively, for the S5 yeast group with different $\mathrm{NH}_{4} \mathrm{Cl}$ concentrations; and 6.58-6.88 log CFU/mL, 7.13-7.40\%, 3.57-3.95, 0.11-0.18\%, $0.40-0.45 \%$, and $4.40-4.50$ Brix, respectively, for the S6 yeast group with different $\mathrm{NH}_{4} \mathrm{Cl}$ concentrations. The highest alcohol contents of the S5 or the S6 yeast group were $7.50 \%$ or $7.40 \%$, respectively, and both occurred in $2.5 \% \mathrm{M}$. nitidum powder particles in an $\mathrm{MNH}$ solution with $0.250 \% \mathrm{NH}_{4} \mathrm{Cl}$.
Table 5 shows the analyses of the yeast count, alcohol content, $\mathrm{pH}$ value, TA, reducing sugar content, and residual sugar content of $2.5 \% \mathrm{MNH}$ solution with various amounts of proline added with fermentation at $25^{\circ} \mathrm{C}$ for 10 days. The yeast count, alcohol content, $\mathrm{pH}$ value, TA, reducing sugar content, and residual sugar content were 7.12-7.58 $\log \mathrm{CFU} / \mathrm{mL}$, $7.17-7.73 \%, 4.03-4.13,0.12-0.16 \%, 0.32-0.41 \%$, and $4.60-4.83$ ${ }^{\circ}$ Brix, respectively, for the S5 yeast group with different proline concentrations; and 6.60-7.10 $\log \mathrm{CFU} / \mathrm{mL}, 7.13-7.86 \%$, $3.92-3.99,0.11-0.16 \%, 0.40-0.45 \%$, and $4.50-4.67{ }^{\circ}$ Brix, respectively, for the S6 yeast group with different proline concentrations. The highest alcohol contents of the S5 or the S6 combination starter were $7.73 \%$ or $7.86 \%$, respectively, and both occurred in $2.5 \% \mathrm{M}$. nitidum powder particles in $\mathrm{MNH}$ solution with $0.500 \%$ proline.

In the M. nitidum wine-producing starter groups, S5 and S6, the organic nitrogen source proline resulted in higher alcohol content than with the mineral nitrogen sources of ammonium chloride or dihydrogen phosphate. At only $7.53 \%$, the crude protein of M. nitidum powder may not have been enough for $S$. cerevisiae growth under alcohol fermentation. In the berry and the must, nitrogen can be found under mineral $\left(\mathrm{NH}_{4}{ }^{+}\right.$, $\mathrm{NO}_{3}^{-}$, and $\mathrm{NO}_{2}{ }^{-}$) and organic (free amino acids, proteins and other nitrogenated organic compounds such as urea, ethyl carbamate and nucleic acids) forms. This nitrogen, called fermentable nitrogen, is used by yeast to carry on the normal alcoholic fermentation of the must [11]. Takagi et al. [38] indicated that, during sake fermentation, yeast cells are exposed to various stresses under anaerobic conditions, including high concentrations of ethanol ( $20 \%$ [vol/vol] $)$. These stresses make it toxic for $S$. cerevisiae, damaging the cell membrane and functional proteins, and gradually reducing cell viability and leading to cell death during fermentation. L-proline is an osmoprotectant and a sweet amino acid that 
Table 4. The analyses of the yeast count, alcohol content, $\mathrm{pH}$ value, titratable acidity, reducing sugar content, and residual sugar content of $2.5 \% \mathrm{M}$. nitidum hydrolysate solution with various contents of ammonium chloride $\left(\mathrm{NH}_{4} \mathrm{Cl}\right)$ added that fermented at $25^{\circ} \mathrm{C}$ for 10 days.

\begin{tabular}{cccccccc}
\hline Groups $^{1}$ & $\begin{array}{c}\mathrm{NH}_{4} \mathrm{Cl} \\
(\%)\end{array}$ & $\begin{array}{c}\text { Yeast count } \\
(\text { Log CFU/mL) }\end{array}$ & $\begin{array}{c}\text { Alcohol content } \\
(\%, \mathrm{v} / \mathrm{v})\end{array}$ & pH value & $\begin{array}{c}\text { Titratable acidity } \\
(\%)\end{array}$ & $\begin{array}{c}\text { Reducing sugar } \\
(\%)\end{array}$ & $\begin{array}{c}\text { Residual sugar } \\
\left({ }^{\circ} \mathrm{Brix}\right)\end{array}$ \\
\hline \multirow{6}{*}{$\mathrm{S} 5$} & 0.000 & $7.30 \pm 0.12^{\mathrm{a}}$ & $7.22 \pm 0.28^{\mathrm{abc}}$ & $4.03 \pm 0.02^{\mathrm{a}}$ & $0.12 \pm 0.00^{\mathrm{de}}$ & $0.35 \pm 0.04^{\mathrm{bc}}$ & $4.60 \pm 0.00^{\mathrm{a}}$ \\
& 0.125 & $7.38 \pm 0.31^{\mathrm{a}}$ & $7.37 \pm 0.23^{\mathrm{ab}}$ & $3.97 \pm 0.01^{\mathrm{ab}}$ & $0.14 \pm 0.02^{\mathrm{cd}}$ & $0.32 \pm 0.12^{\mathrm{c}}$ & $4.50 \pm 0.10 \mathrm{a}^{\mathrm{b}}$ \\
& 0.250 & $7.43 \pm 0.15^{\mathrm{a}}$ & $7.50 \pm 0.25^{\mathrm{a}}$ & $3.88 \pm 0.00^{\mathrm{bc}}$ & $0.15 \pm 0.00^{\mathrm{bc}}$ & $0.38 \pm 0.02^{\mathrm{abc}}$ & $4.60 \pm 0.00^{\mathrm{a}}$ \\
& 0.500 & $7.33 \pm 0.12^{\mathrm{a}}$ & $7.34 \pm 0.13^{\mathrm{ab}}$ & $3.79 \pm 0.01^{\mathrm{c}}$ & $0.18 \pm 0.02^{\mathrm{a}}$ & $0.36 \pm 0.03^{\mathrm{abc}}$ & $4.57 \pm 0.03^{\mathrm{a}}$ \\
& 1.000 & $7.15 \pm 0.04^{\mathrm{ab}}$ & $7.01 \pm 0.11^{\mathrm{c}}$ & $3.61 \pm 0.01^{\mathrm{d}}$ & $0.17 \pm 0.02^{\mathrm{ab}}$ & $0.41 \pm 0.00^{\mathrm{abc}}$ & $4.57 \pm 0.03^{\mathrm{a}}$ \\
\hline \multirow{3}{*}{$\mathrm{S} 6$} & 0.000 & $6.73 \pm 0.06^{\mathrm{c}}$ & $7.13 \pm 0.08^{\mathrm{bc}}$ & $3.95 \pm 0.00^{\mathrm{ab}}$ & $0.11 \pm 0.00^{\mathrm{e}}$ & $0.45 \pm 0.00^{\mathrm{a}}$ & $4.50 \pm 0.06^{\mathrm{ab}}$ \\
& 0.125 & $6.88 \pm 0.03^{\mathrm{bc}}$ & $7.21 \pm 0.16^{\mathrm{abc}}$ & $3.86 \pm 0.00^{\mathrm{bc}}$ & $0.13 \pm 0.01^{\mathrm{cde}}$ & $0.40 \pm 0.06^{\mathrm{ab}}$ & $4.50 \pm 0.00^{\mathrm{ab}}$ \\
& 0.250 & $6.80 \pm 0.26^{\mathrm{c}}$ & $7.40 \pm 0.19^{\mathrm{ab}}$ & $3.78 \pm 0.01^{\mathrm{c}}$ & $0.15 \pm 0.00^{\mathrm{bc}}$ & $0.41 \pm 0.03^{\mathrm{abc}}$ & $4.43 \pm 0.06^{\mathrm{b}}$ \\
& 0.500 & $6.70 \pm 0.30^{\mathrm{c}}$ & $7.36 \pm 0.16^{\mathrm{ab}}$ & $3.81 \pm 0.02^{\mathrm{c}}$ & $0.18 \pm 0.01^{\mathrm{a}}$ & $0.44 \pm 0.04^{\mathrm{ab}}$ & $4.50 \pm 0.10^{\mathrm{ab}}$ \\
& 1.000 & $6.58 \pm 0.22^{\mathrm{c}}$ & $7.16 \pm 0.31^{\mathrm{bc}}$ & $3.57 \pm 0.00^{\mathrm{d}}$ & $0.17 \pm 0.00^{\mathrm{ab}}$ & $0.45 \pm 0.02^{\mathrm{a}}$ & $4.40 \pm 0.00^{\mathrm{b}}$ \\
\hline
\end{tabular}

': S5: M. nitidum hydrolysate solution $+15 \%$ sucrose fermented by S. cerevisiae BCRC21686 (2.5\%) and BCRC21962 (2.5\%); S6: M. nitidum hydrolysate solution $+15 \%$ sucrose fermented by S. cerevisiae BCRC21824 (2.5\%) and BCRC21962 (2.5\%).

2: Each value is the means \pm standard deviation $(n=3)$ and the different superscript letters in the same column are significantly different $(p<$ $0.05)$.

Table 5. The analyses of the yeast count, alcohol content, $\mathrm{pH}$ value, titratable acidity, reducing sugar content, an residual sugar content of $2.5 \% \mathrm{M}$. nitidum hydrolysate solution with various contents of proline added that fermented at $25^{\circ} \mathrm{C}$ for 10 days.

\begin{tabular}{|c|c|c|c|c|c|c|c|}
\hline Groups $^{1}$ & $\begin{array}{c}\text { Proline } \\
(\%)\end{array}$ & $\begin{array}{c}\text { Yeast count } \\
(\text { Log CFU/mL) }\end{array}$ & $\begin{array}{c}\text { Alcohol content } \\
(\%, \mathrm{v} / \mathrm{v})\end{array}$ & $\mathrm{pH}$ value & $\begin{array}{c}\text { Titratable acidity } \\
(\%)\end{array}$ & $\begin{array}{c}\text { Reducing sugar } \\
(\%)\end{array}$ & $\begin{array}{c}\text { Residual sugar } \\
\left({ }^{\circ} \text { Brix }\right)\end{array}$ \\
\hline \multirow{5}{*}{ S5 } & 0.000 & $7.30 \pm 0.13^{\mathrm{ab} 2}$ & $7.22 \pm 0.10^{\mathrm{cd}}$ & $4.03 \pm 0.02^{\mathrm{abc}}$ & $0.12 \pm 0.00^{\mathrm{cd}}$ & $0.35 \pm 0.04^{\mathrm{de}}$ & $4.63 \pm 0.06^{\mathrm{bc}}$ \\
\hline & 0.125 & $7.42 \pm 0.28^{\mathrm{a}}$ & $7.32 \pm 0.09^{\mathrm{c}}$ & $4.08 \pm 0.02^{\mathrm{ab}}$ & $0.13 \pm 0.01^{\mathrm{bcd}}$ & $0.36 \pm 0.03^{\text {cde }}$ & $4.70 \pm 0.00^{\mathrm{b}}$ \\
\hline & 0.250 & $7.51 \pm 0.22^{\mathrm{a}}$ & $7.51 \pm 0.07^{\mathrm{b}}$ & $4.11 \pm 0.04^{\mathrm{ab}}$ & $0.14 \pm 0.01^{\mathrm{abc}}$ & $0.38 \pm 0.02^{\text {bcde }}$ & $4.70 \pm 0.00^{b}$ \\
\hline & 0.500 & $7.58 \pm 0.06^{\mathrm{a}}$ & $7.73 \pm 0.12^{\mathrm{a}}$ & $4.13 \pm 0.01^{\mathrm{a}}$ & $0.15 \pm 0.01^{\mathrm{ab}}$ & $0.41 \pm 0.06^{\mathrm{abcd}}$ & $4.83 \pm 0.06^{\mathrm{a}}$ \\
\hline & 1.000 & $7.12 \pm 0.18^{\mathrm{bc}}$ & $7.17 \pm 0.15^{\mathrm{cd}}$ & $4.09 \pm 0.00^{\mathrm{ab}}$ & $0.16 \pm 0.00^{\mathrm{a}}$ & $0.32 \pm 0.01^{\mathrm{e}}$ & $4.60 \pm 0.00^{\mathrm{cd}}$ \\
\hline \multirow{5}{*}{ S6 } & 0.000 & $6.73 \pm 0.06^{\mathrm{de}}$ & $7.13 \pm 0.13^{\mathrm{d}}$ & $3.95 \pm 0.00^{\mathrm{c}}$ & $0.11 \pm 0.00^{\mathrm{d}}$ & $0.45 \pm 0.00^{\mathrm{a}}$ & $4.53 \pm 0.06^{\mathrm{de}}$ \\
\hline & 0.125 & $6.78 \pm 0.12^{\mathrm{de}}$ & $7.34 \pm 0.05^{\mathrm{c}}$ & $3.92 \pm 0.03^{\mathrm{c}}$ & $0.12 \pm 0.02^{\mathrm{cd}}$ & $0.42 \pm 0.02^{\mathrm{abc}}$ & $4.60 \pm 0.00^{\mathrm{cd}}$ \\
\hline & 0.250 & $6.89 \pm 0.15^{\mathrm{cd}}$ & $7.56 \pm 0.06^{b}$ & $3.99 \pm 0.01 b^{c}$ & $0.13 \pm 0.02^{\mathrm{bcd}}$ & $0.43 \pm 0.06^{\mathrm{ab}}$ & $4.50 \pm 0.00^{\mathrm{e}}$ \\
\hline & 0.500 & $7.10 \pm 0.17^{\mathrm{bc}}$ & $7.86 \pm 0.14^{\mathrm{a}}$ & $3.92 \pm 0.02^{\mathrm{c}}$ & $0.14 \pm 0.00^{\mathrm{abc}}$ & $0.44 \pm 0.01^{\mathrm{ab}}$ & $4.67 \pm 0.03^{\mathrm{bc}}$ \\
\hline & 1.000 & $6.60 \pm 0.09^{\mathrm{e}}$ & $7.19 \pm 0.05^{\mathrm{cd}}$ & $3.93 \pm 0.01^{\mathrm{c}}$ & $0.16 \pm 0.01^{\mathrm{a}}$ & $0.40 \pm 0.02^{\mathrm{abcd}}$ & $4.60 \pm 0.00^{\mathrm{cd}}$ \\
\hline
\end{tabular}

${ }^{1}$ : S5: M. nitidum hydrolysate solution + 15\% sucrose fermented by S. cerevisiae BCRC21686 (2.5\%) and BCRC21962 (2.5\%); S6: M. nitidum hydrolysate solution $+15 \%$ sucrose fermented by S. cerevisiae BCRC21824 (2.5\%) and BCRC21962 (2.5\%).

2: Each value is the means \pm standard deviation $(\mathrm{n}=3)$. The different superscript letters in the same column are significantly different $(p<$ $0.05)$.

helps protect yeast cells from damage by freezing, desiccation, or oxidative stress. L-proline enhances the stability of proteins and membranes in environments with low water activity and inhibits aggregation during protein refolding. This suggests that L-proline could play a crucial role in reducing ethanol stress by preventing protein denaturation and membrane disorder during sake fermentation [31, 38]. Hence, it was not unexpected when proline revealed a higher ethanol content than ammonium chloride or dihydrogen phosphate. However, the results showed that the nitrogen sources of ammonium chloride, dihydrogen phosphate, or proline were greater (from $0.500 \%$ raised to 1.000 ), causing less ethanol; perhaps, great osmotic pressure led to this phenomenon.

\section{Inoculation Concentration of $M$. nitidum Wine-Producing Starter Groups}

The analyses of the yeast count, alcohol content, $\mathrm{pH}$ value, TA, reducing sugar content, and residual sugar content of $2.5 \% \mathrm{MNH}$ solution with different starter concentrations added and with fermentation at $25^{\circ} \mathrm{C}$ for 10 days are shown in Table 6. The yeast count, alcohol content, $\mathrm{pH}$ value, TA, reducing sugar content, and residual sugar content were 7.14-7.75 log CFU/mL, 7.21-7.87\%, 4.03-4.14, 0.12-0.15\%, $0.39-0.45 \%$, and $4.50-4.90$ Brix, respectively, for the S5 yeast 
Table 6. The analyses of the yeast count, alcohol content, $\mathrm{pH}$ value, titratable acidity, reducing sugar content, and residual sugar content of $2.5 \% \mathrm{M}$. nitidum hydrolysate solution with different starter contents added that fermented at $25^{\circ} \mathrm{C}$ for 10 days.

\begin{tabular}{cccccccc}
\hline Groups $^{1}$ & $\begin{array}{c}\text { Starter } \\
\text { contents }(\%)\end{array}$ & $\begin{array}{c}\text { Yeast count } \\
(\text { Log CFU/mL) }\end{array}$ & $\begin{array}{c}\text { Alcohol content } \\
(\%, \mathrm{v} / \mathrm{v})\end{array}$ & pH value & $\begin{array}{c}\text { Titratable acidity } \\
(\%)\end{array}$ & $\begin{array}{c}\text { Reducing sugar } \\
(\%)\end{array}$ & $\begin{array}{c}\text { Residual sugar } \\
\left({ }^{\circ} B r i x\right)\end{array}$ \\
\hline \multirow{3}{*}{ S5 } & 2 & $7.28 \pm 0.12^{\mathrm{c} 2}$ & $7.51 \pm 0.11^{\mathrm{de}}$ & $4.03 \pm 0.21^{\mathrm{bcd}}$ & $0.13 \pm 0.00^{\mathrm{bc}}$ & $0.40 \pm 0.04^{\mathrm{abc}}$ & $4.73 \pm 0.12^{\mathrm{bcd}}$ \\
& 4 & $7.68 \pm 0.14^{\mathrm{ab}}$ & $7.87 \pm 0.05^{\mathrm{b}}$ & $4.11 \pm 0.01^{\mathrm{abc}}$ & $0.15 \pm 0.01^{\mathrm{a}}$ & $0.45 \pm 0.04^{\mathrm{a}}$ & $4.90 \pm 0.10^{\mathrm{a}}$ \\
& 6 & $7.75 \pm 0.12^{\mathrm{a}}$ & $7.66 \pm 0.03^{\mathrm{cd}}$ & $4.14 \pm 0.02^{\mathrm{ab}}$ & $0.14 \pm 0.00^{\mathrm{ab}}$ & $0.43 \pm 0.05^{\mathrm{abc}}$ & $4.73 \pm 0.06^{\mathrm{de}}$ \\
& 8 & $7.23 \pm 0.05^{\mathrm{cd}}$ & $7.39 \pm 0.06^{\mathrm{e}}$ & $4.11 \pm 0.01^{\mathrm{abc}}$ & $0.12 \pm 0.01^{\mathrm{c}}$ & $0.44 \pm 0.02^{\mathrm{ab}}$ & $4.60 \pm 0.00^{\mathrm{ef}}$ \\
& 10 & $7.14 \pm 0.09^{\mathrm{cde}}$ & $7.21 \pm 0.13^{\mathrm{f}}$ & $4.05 \pm 0.01^{\mathrm{bcd}}$ & $0.13 \pm 0.01^{\mathrm{bc}}$ & $0.39 \pm 0.08^{\mathrm{bc}}$ & $4.50 \pm 0.00^{\mathrm{f}}$ \\
\hline \multirow{3}{*}{$\mathrm{S} 6$} & 2 & $7.00 \pm 0.07^{\mathrm{e}}$ & $7.82 \pm 0.08^{\mathrm{b}}$ & $3.87 \pm 0.00^{\mathrm{e}}$ & $0.14 \pm 0.00^{\mathrm{ab}}$ & $0.41 \pm 0.01^{\mathrm{abc}}$ & $4.80 \pm 0.10^{\mathrm{ab}}$ \\
& 4 & $7.25 \pm 0.16^{\mathrm{c}}$ & $8.07 \pm 0.09^{\mathrm{a}}$ & $3.93 \pm 0.00^{\mathrm{de}}$ & $0.13 \pm 0.01^{\mathrm{bc}}$ & $0.38 \pm 0.11^{\mathrm{c}}$ & $4.77 \pm 0.06^{\mathrm{bc}}$ \\
& 6 & $7.52 \pm 0.19^{\mathrm{b}}$ & $7.73 \pm 0.03^{\mathrm{bc}}$ & $3.99 \pm 0.01^{\mathrm{cd}}$ & $0.13 \pm 0.02^{\mathrm{bc}}$ & $0.45 \pm 0.02^{\mathrm{a}}$ & $4.80 \pm 0.00^{\mathrm{ab}}$ \\
& 8 & $7.20 \pm 0.10^{\mathrm{cde}}$ & $7.53 \pm 0.21^{\mathrm{de}}$ & $4.07 \pm 0.01^{\mathrm{abc}}$ & $0.14 \pm 0.01^{\mathrm{ab}}$ & $0.24 \pm 0.01^{\mathrm{d}}$ & $4.67 \pm 0.06^{\mathrm{cde}}$ \\
& 10 & $7.01 \pm 0.18^{\mathrm{de}}$ & $7.40 \pm 0.11^{\mathrm{e}}$ & $4.18 \pm 0.00^{\mathrm{a}}$ & $0.15 \pm 0.00^{\mathrm{a}}$ & $0.20 \pm 0.01^{\mathrm{d}}$ & $4.77 \pm 0.06^{\mathrm{bc}}$ \\
\hline
\end{tabular}

${ }^{1}$ : S5: M. nitidum hydrolysate solution $+15 \%$ sucrose fermented by S. cerevisiae BCRC21686 (2.5\%) and BCRC21962 (2.5\%); S6: M. nitidum hydrolysate solution $+15 \%$ sucrose fermented by S. cerevisiae BCRC21824 (2.5\%) and BCRC21962 (2.5\%).

2: Each value is the means \pm standard deviation $(\mathrm{n}=3)$. The different superscript letters in the same column are significantly different $(p<$ $0.05)$.

group with different inoculation concentrations; and 7.00-7.52 $\log$ CFU/mL, 7.40-8.07\%, 3.87-4.18, 0.13-0.15\%, 0.20-0.45\%, and 4.67-4.80 ${ }^{\circ}$ Brix, respectively, for the S6 yeast group with different inoculation concentrations. The highest alcohol contents of the S5 or the S6 yeast group were $7.87 \%$ or $8.07 \%$, respectively, and both occurred in $2.5 \% \mathrm{M}$. nitidum powder particles in MNH solution with a $4 \%$ yeast concentration. In this study, when the $S$. cerevisiae inoculation concentration was higher, the $S$. cerevisiae content formed more rapidly, and higher alcohol content was produced in $M$. nitidum wine. Vriesekoop and Pamment [41] indicated that during industrial fermentations, microorganisms may be exposed to a range of unfavorable conditions that can impede growth and fermentation. The other reason is that more inoculation concentration may cause growth of $S$. cerevisiae that stops ethanol production. On the basis of the wine cost of fermented M. nitidum, the $S$. cerevisiae inoculation concentration was $4 \%$ for the S5 or S6 starter combinations.

In brief, a higher alcohol content results in more TA, less reducing sugar, less residual sugar, and lower $\mathrm{pH}$ in tests of the concentrations of $M$. nitidum powder particles, carbon sources, nitrogen sources, and wine-producing starter groups.

\section{Fermentation Time of M. nitidum Wines}

To determine the best fermentation day and the superior chemical composition of $M$. nitidum wines, this study integrated the above powder particle concentrations of M. nitidum, carbon sources, nitrogen sources, and starter groups concentration results under the following fermentation conditions: $2.5 \%$ M. nitidum powder particles, $10 \%-20 \%$ sucrose, $0.5 \%$ proline, and $4 \%$ yeast group inoculated concentrations $(2 \%$ for each) at $0,5,7,10,14,18$, or 21 day. The M. nitidum wine experiments were carried out under these conditions, as shown in Fig. 1.
The changes in yeast counts of $2.5 \% \mathrm{MNH}$ solutions with $10 \%-20 \%$ sucrose fermented by the $4 \%$ S 5 or S6 yeast groups at $25^{\circ} \mathrm{C}$ over 21 days are displayed in Fig. 1(a). The yeast counts increased sharply from the initial fermentation stage (6.25-6.35 $\log \mathrm{CFU} / \mathrm{mL}$ ) to the 5th day (7.39-7.89 CFU/mL), and slowly decreased with $M$. nitidum wine fermentation from the 5 th to $21 \mathrm{st}$ day. Fig. 1(b) shows the changes in alcohol content of $2.5 \% \mathrm{MNH}$ solution with $10 \%-20 \%$ sucrose fermented by the $4 \% \mathrm{~S} 5$ and S6 yeast groups at $25^{\circ} \mathrm{C}$ for 21 days. The alcohol contents of $M$. nitidum wines containing $10 \%$, $15 \%$, and $20 \%$ sucrose were $5.22-5.32 \%, 7.89-8.11 \%$ and $10.09-10.24 \%$, respectively; their alcohol transform ratios were $81.7-83.3 \%, 82.3-84.6 \%$, and $78.7-80.2 \%$ after 7,10 , or 14 days, respectively. They reached a stationary phase without undergoing any changes. The changes in $\mathrm{pH}$ values of $2.5 \% \mathrm{MNH}$ solution with $10 \%-20 \%$ sucrose fermented by the $4 \% \mathrm{~S} 5$ and $\mathrm{S} 6$ yeast groups at $25^{\circ} \mathrm{C}$ for 21 days are shown in Fig. 1(c). The $\mathrm{pH}$ values of all $M$. nitidum wines ranged from 5.56-5.64 at the onset stage, then sharply decreased to 3.514.01 after 5 days of fermentation, rose again to 3.64-4.21 during 7-10 days, and finally maintained at 3.79-4.19 until the 21 st day. Fig. 1(d) shows the changes in TA of $2.5 \% \mathrm{MNH}$ solution with $10 \%-20 \%$ sucrose fermented by the $4 \%$ S5 and S6 yeast groups at $25^{\circ} \mathrm{C}$ for 21 days. The TA content of $M$. nitidum wines containing $10 \%, 15 \%$, or $20 \%$ sharply increased to $0.11-0.12 \%, 0.13-0.14 \%$, or $0.16-0.17 \%$ after 7,10 , or 14 days, respectively, then stayed at $0.09-0.11 \%, 0.13-0.15 \%$, or $0.16-0.17 \%$, respectively, until the 21 st day. The changes in the reducing sugar content of $2.5 \% \mathrm{MNH}$ solution with $10 \%-20 \%$ sucrose fermented by the $4 \%$ S5 and S6 yeast groups at $25^{\circ} \mathrm{C}$ for 21 days are shown in Fig. 1(e). The reduced sugar content of $M$. nitidum wines containing $10 \%, 15 \%$, or $20 \%$ sucrose sharply increased by fermentation day 5 , and took $0.23-0.26 \%, 0.33-0.44 \%$, or $0.53-0.58 \%$ at the 10,14 , or 

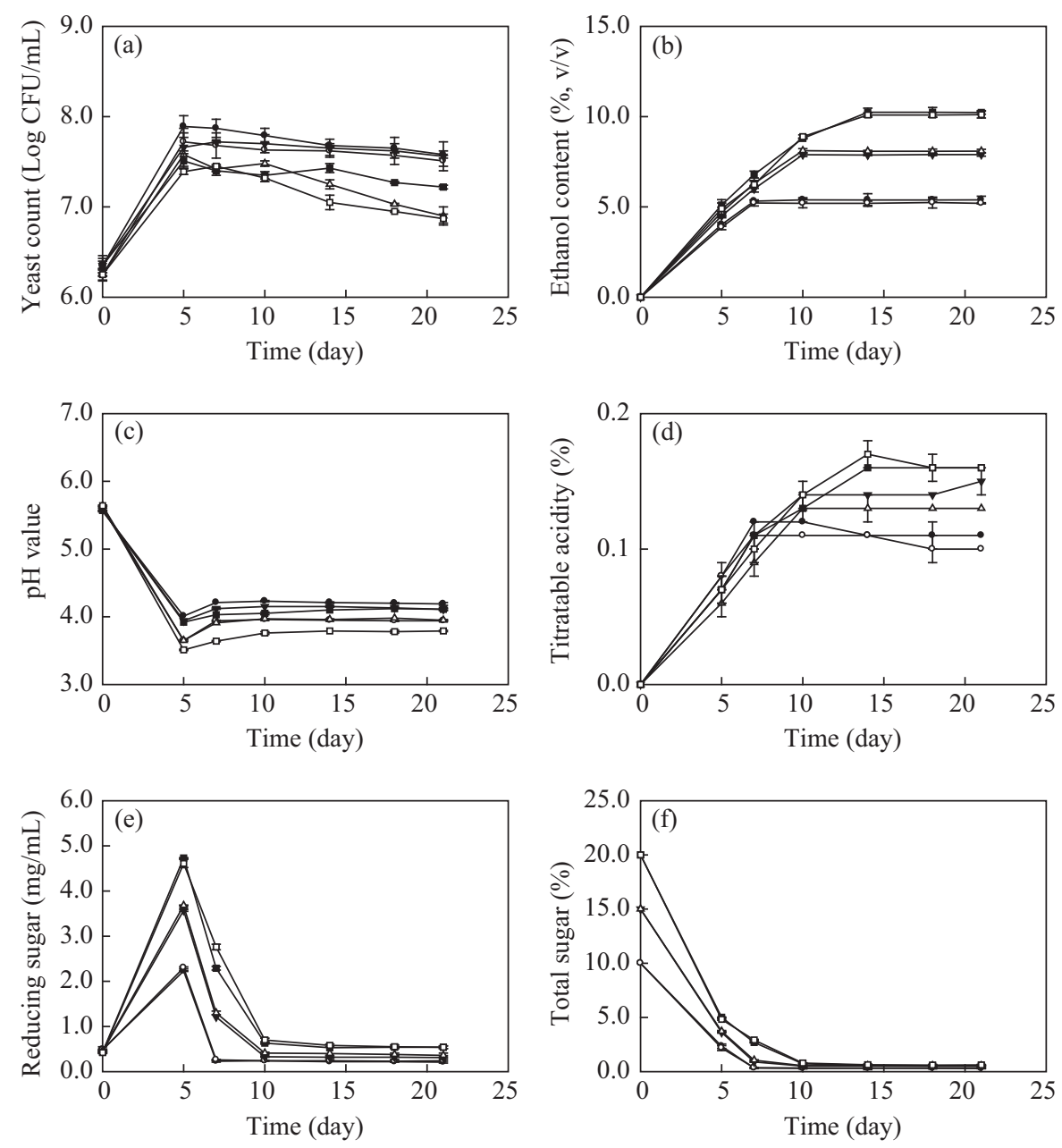

Fig. 1. The changes in (a) yeast count; (b) alcohol content; (c) pH value; (d) titratable acidity; (e) reducing sugar content; and (f) total sugar content of $2.5 \% \mathrm{M}$. nitidum hydrolysate solution containing $10 \%-20 \%$ sucrose with fermentation by $4 \% \mathrm{~S} 5$ and $\mathrm{S} 6$ combination starters at $25^{\circ} \mathrm{C}$ over 21 days. ๑: S5-10\% sucrose; O: S6-10\% sucrose; $\nabla$ : S5-15\% sucrose; $\nabla: \mathrm{S6-15 \%}$ sucrose; $\square: \mathrm{S5-20 \%}$ sucrose; $\square$ : S6-20\% sucrose.

21 day, respectively, reaching a stationary phase without undergoing any changes. Fig. 1(f) shows the changes in total sugar content of $2.5 \%$ MNH solution with $10 \%-20 \%$ sucrose fermented by the $4 \% \mathrm{~S} 5$ and S6 yeast groups at $25^{\circ} \mathrm{C}$ for 21 days. The total sugar content of $M$. nitidum wines containing $10 \%, 15 \%$, or $20 \%$ sucrose was $2.17-2.34 \%, 3.61-3.72 \%$, or $4.82-5.01 \%$ after 5 days, respectively, and decreased to $0.33-0.35 \%, 0.51-0.54 \%$, or $0.59-0.63 \%$ after 10,14 , or 21 days, respectively, reaching a stationary phase without undergoing any changes.

Many studies have been done on wines fermented with different raw materials with $S$. cerevisiae. Reddy and Reddy [34] used S. cerevisiae inoculated into a high $(30-40 \%$, w/v) sugar-containing medium with and without supplementation of horse gram flour. The fermentation rate increased in 3 to 5 days with increased viable cell counts, and decreased with the fermentation time in the end. The residual sugar content was also reduced by an increase in alcohol content. Malacrinò et al. [27] carried out alcoholic fermentation using four commercial strains of fermented grape musts with a sugar concentration of $35{ }^{\circ}$ Brix. Ethanol production started quickly in trials of inoculated strains, reaching a maximum production rate after 12 day, with a drastic reduction of ethanol production observed after 30 days. There is a strong correlation between the amount of sugar and the assimilable nitrogen consumption rate, with most of the TAN (total assimilable nitrogen) present in the must being utilized at the beginning of alcoholic fermentation in correspondence with the highest rate of sugar consumption. Therefore, $10 \%, 15 \%$, or $20 \%$ sucrose concentrations were added to $25^{\circ} \mathrm{C} \mathrm{M}$. nitidum wines fermented from $2.5 \% M$. nitidum powder particles, $0.5 \%$ proline, and $4 \%$ starter groups after 7,10 , or 14 days, respectively.

\section{Composition Changes of M. nitidum Wine Aging}

The changes in alcohol content on the aging period of $M$. nitidum wines fermented by S5 and $\mathrm{S} 6$ yeast groups are shown in Fig. 2(a) and Fig. 3(a). Whether at 15 or $25^{\circ} \mathrm{C}$, the alcohol contents in M. nitidum wines containing $10 \%, 15 \%$, or $20 \%$ 

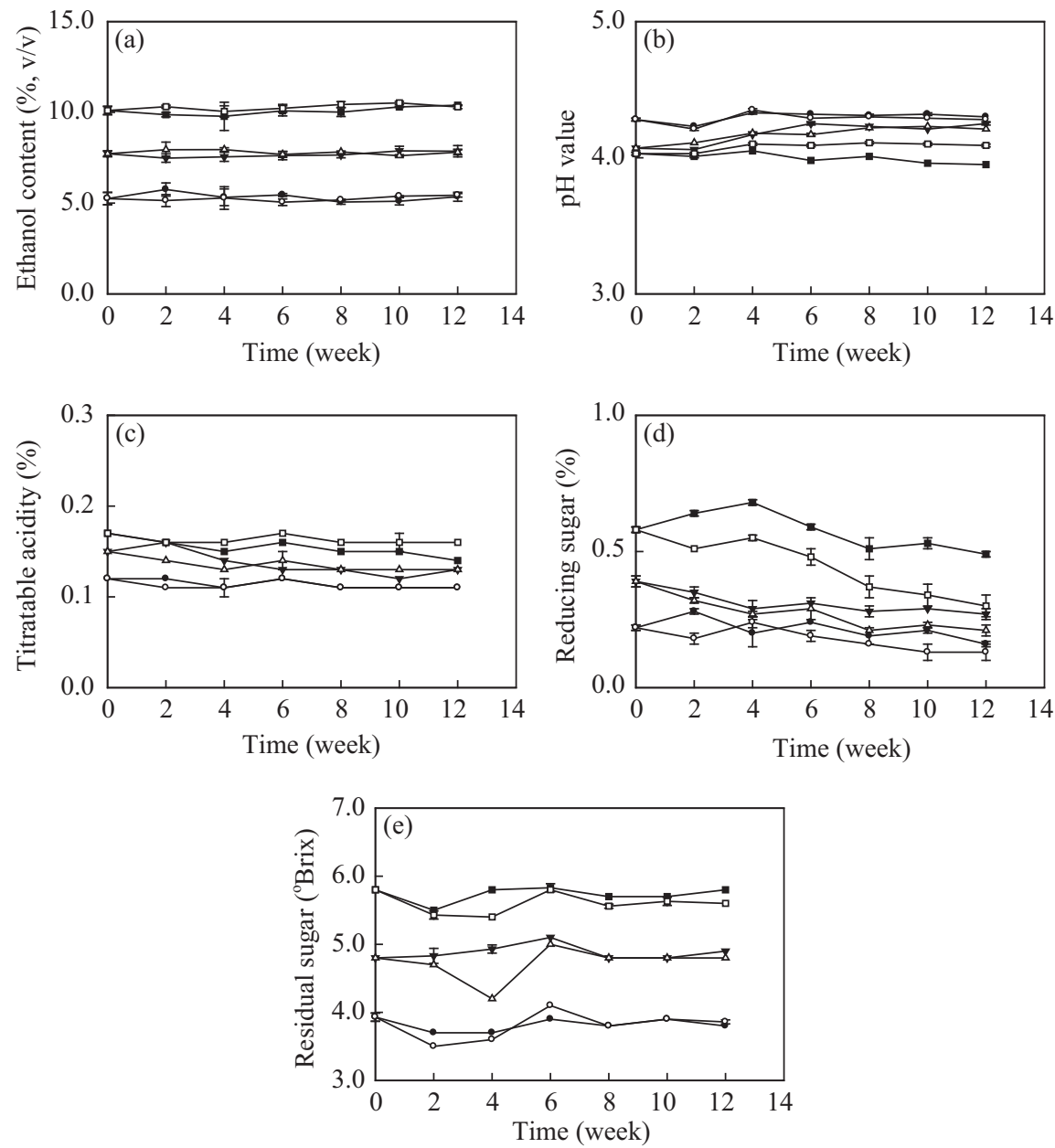

Fig. 2. The changes of (a) alcohol content; (b) pH value; (c) titratable acidity; (d) reducing sugar content; and (e) total sugar content on the aging period of $\mathrm{M}$. nitidum wines fermented by the $\mathrm{S} 5$ yeast group. $\bullet: 10 \%$ sucrose- $15^{\circ} \mathrm{C} ; O: 10 \%$ sucrose- $25^{\circ} \mathrm{C} ; \nabla: 15 \%$ sucrose- $15{ }^{\circ} \mathrm{C} ; \nabla: 15 \%$ sucrose- $25^{\circ} \mathrm{C} ; \square: 20 \%$ sucrose $-15^{\circ} \mathrm{C} ; \square: 20 \%$ sucrose- $25^{\circ} \mathrm{C}$.

sucrose fermented by the S5 and the S6 yeast groups were $5.2-5.5 \%, 7.7-8.4 \%$, and $10.1-10.3 \%$, respectively. The alcohol contents of $M$. nitidum wines which did not undergo distinct changes, might have resulted because the $M$. nitidum wines were sealed up in bottles during the aging period, with very little alcohol evaporating. The changes in $\mathrm{pH}$ value and TA in the aging period of $M$. nitidum wines fermented by S5 and S6 yeast groups are shown in Fig. 2(b, c) and Fig. 3(b, c): the $\mathrm{pH}$ values increased slightly from $3.85 \%-4.27 \%$ to $3.93 \%$ $4.29 \%$, while the TA showed a small decrease from $0.12 \%$ $0.17 \%$ to $0.11 \%-0.16 \%$ after three months. The changes of the aging period of $M$. nitidum wines fermented by S5 and S6 yeast groups by reducing sugar along with decreased aging time are shown in Fig. 2(d) and Fig. 3(d). After the M. nitidum wines had aged, reducing sugar decreased from $0.22 \%-0.58 \%$ to $0.13 \%-0.39 \%\left(25^{\circ} \mathrm{C}\right)$ or $0.16 \%-0.49 \%\left(15^{\circ} \mathrm{C}\right)$. Fig. $2(\mathrm{e})$ and Fig. 3(e) show the changes in residual sugar content in the aging period of $M$. nitidum wines fermented by the S5 and S6 yeast groups with no distinct changes in residual sugar after three months, and their contents ranged from 3.5-3.8, 4.7-4.9, or 5.5-5.8 Brix for M. nitidum wines containing $10 \%, 15 \%$, or $20 \%$ sucrose. Moreno and Azpilicueta [30] studied wines that had been aged in oak barrels at the half-way stage of storage (243 days) and at the end of aging (540 days). The $\mathrm{pH}$ values, total acidity, and volatile acidity increased at 243 and 540 days for young wine. The alcohol content and free $\mathrm{SO}_{2}$ content decreased at 243 and 540 days for young wine.

Fig. 4 shows the changes in the Hunter L, a, and b values in the aging period of $M$. nitidum wines fermented by the (a) S5 and (b) S6 yeast groups. Before the aging of $M$. nitidum wines fermented by the S5 and S6 yeast groups, the Hunter L values were 15.53-15.80 and 15.10-15.86, respectively. All the values decreased at $15^{\circ} \mathrm{C}$ (S5: 14.21-14.86; S6: 14.58-14.88) and $25^{\circ} \mathrm{C}$ (S5: 14.19-14.32; S6: 13.62-14.17) after the aging period. Before the aging of $M$. nitidum wines fermented by the S5 and S6 yeast groups, the Hunter a values were $-1.99 \sim-1.88$ and $-1.91 \sim-1.87$, respectively, and all increased at $15^{\circ} \mathrm{C}$ (S5: -1.89 -1.67; S6: $-1.69 \sim-1.60)$ and $25^{\circ} \mathrm{C}$ (S5: -1.84 -1.62; S6: $-1.54 \sim-1.50)$ after the aging period. Before the aging of $M$. nitidum wines fermented by the S5 and S6 yeast groups, the 

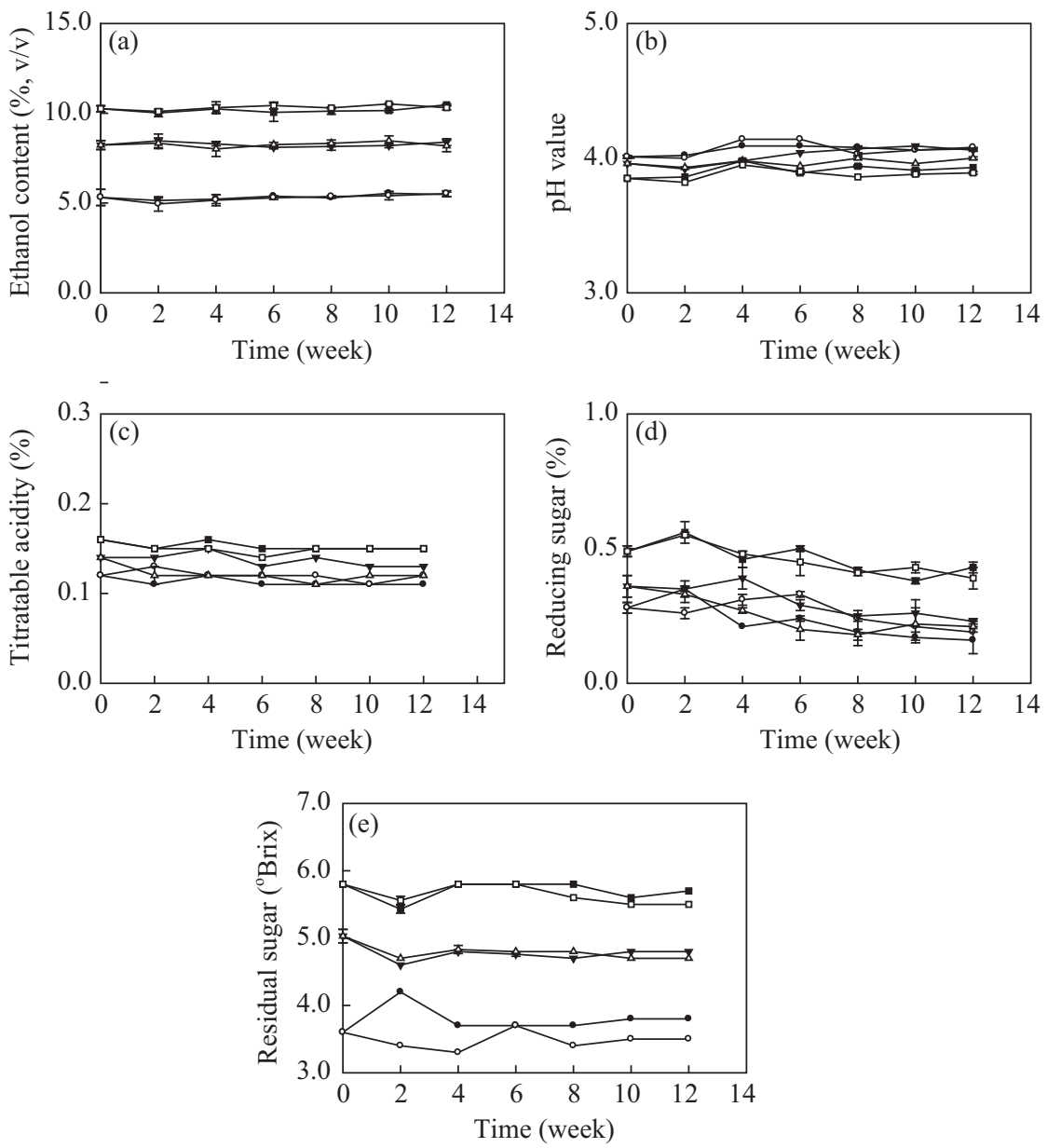

Fig. 3. The changes of (a) alcohol content; (b) pH value; (c) titratable acidity; (d) reducing sugar content; and (e) total sugar content on aging period of $M$. nitidum wines fermented by $S 6$ yeast group. $\bullet: 10 \%$ sucrose- $15^{\circ} \mathrm{C} ; \bigcirc: 10 \%$ sucrose- $25^{\circ} \mathrm{C} ; \nabla: 15 \%$ sucrose- $15^{\circ} \mathrm{C} ; \nabla: 15 \%$ sucrose- $25^{\circ} \mathrm{C} ; \square$ : $20 \%$ sucrose- $15^{\circ} \mathrm{C}$; $\square: 20 \%$ sucrose- $25^{\circ} \mathrm{C}$.
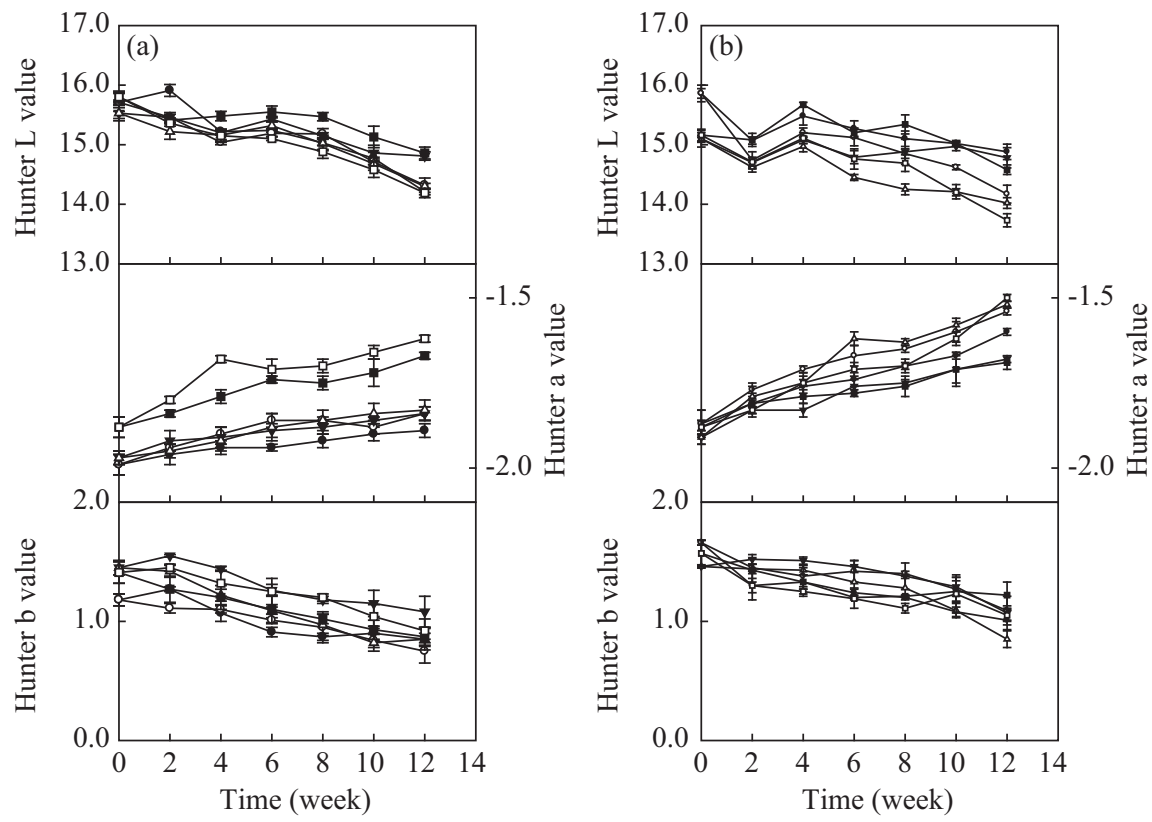

Fig. 4. The changes of Hunter $\mathrm{L}$, a, and b value on the aging period of $M$. nitidum wines fermented by (a) S5 and (b) S6 yeast groups. $\bullet: 10 \%$ sucrose- $15^{\circ} \mathrm{C} ;$ O: $10 \%$ sucrose- $25^{\circ} \mathrm{C} ; \nabla: 15 \%$ sucrose $-15^{\circ} \mathrm{C} ; \nabla: 15 \%$ sucrose- $25^{\circ} \mathrm{C} ; \mathrm{m}: 20 \%$ sucrose- $15^{\circ} \mathrm{C} ; \square: 20 \%$ sucrose- $25^{\circ} \mathrm{C}$. 
Table 7. Results of the sensory evaluation for $M$. nitidum wines with $10 \%-20 \%$ sucrose.

\begin{tabular}{cccccc}
\hline Groups $^{1}$ & Sucrose content (\%) & Color $^{2}$ & Flavor & Taste & Preference \\
\hline \multirow{3}{*}{ Mn-W-S5 } & 10 & $6.13 \pm 2.94^{\mathrm{a} 3}$ & $5.10 \pm 2.75^{\mathrm{c}}$ & $5.35 \pm 1.88^{\mathrm{b}}$ & $5.20 \pm 1.76^{\mathrm{c}}$ \\
& 15 & $6.05 \pm 1.58^{\mathrm{a}}$ & $5.28 \pm 1.72^{\mathrm{bc}}$ & $5.60 \pm 2.02^{\mathrm{ab}}$ & $5.45 \pm 1.25^{\mathrm{bc}}$ \\
\hline \multirow{3}{*}{ Mn-W-S6 } & 20 & $6.08 \pm 1.85^{\mathrm{a}}$ & $5.82 \pm 1.64^{\mathrm{ab}}$ & $5.95 \pm 1.82^{\mathrm{a}}$ & $5.97 \pm 2.04^{\mathrm{ab}}$ \\
\hline & 10 & $6.10 \pm 1.43^{\mathrm{a}}$ & $5.27 \pm 1.83^{\mathrm{bc}}$ & $5.15 \pm 2.15^{\mathrm{b}}$ & $5.33 \pm 2.12^{\mathrm{c}}$ \\
& 15 & $6.07 \pm 1.32^{\mathrm{a}}$ & $5.36 \pm 1.89^{\mathrm{bc}}$ & $5.38 \pm 1.91^{\mathrm{b}}$ & $5.43 \pm 1.20^{\mathrm{bc}}$ \\
\hline
\end{tabular}

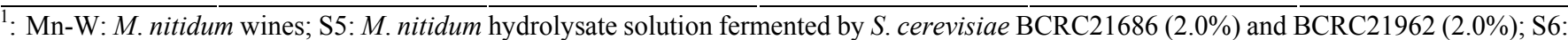
M. nitidum hydrolysate solution fermented by S. cerevisiae BCRC21824 (2.0\%) and BCRC21962 (2.0\%); 10\%-20\% sucrose: the fermented wines of the $M$. nitidum hydrolysate solution with $10 \%-20 \%$ sucrose added.

2: Grade: $1=$ dislike extremely; $3=$ dislike; $5=$ neither like nor dislike; $7=$ like; $9=$ like extremely.

': Each value is the means \pm standard deviation $(n=16)$. The different superscript letters in the same column are significantly different $(p<$ $0.05)$.

Table 8. Results of the sensory evaluation of $M$. nitidum wines treated at different aging temperatures.

\begin{tabular}{cccccc}
\hline Groups $^{1}$ & Aging temperature & Color $^{2}$ & Flavor & Taste & Preference \\
\hline Mn-W-S5-20s & \multirow{2}{*}{$15^{\circ} \mathrm{C}$ aging } & $6.21 \pm 1.43^{\mathrm{a} 3}$ & $6.49 \pm 1.95^{\mathrm{a}}$ & $6.43 \pm 0.87^{\mathrm{a}}$ & $6.52 \pm 1.85^{\mathrm{a}}$ \\
Mn-W-S6-20s & & $6.13 \pm 2.26^{\mathrm{a}}$ & $6.57 \pm 2.13^{\mathrm{a}}$ & $6.54 \pm 1.14^{\mathrm{a}}$ & $6.70 \pm 1.73^{\mathrm{a}}$ \\
\hline Mn-W-S5-20s & \multirow{2}{*}{$25^{\circ} \mathrm{C}$ aging } & $5.92 \pm 2.01^{\mathrm{a}}$ & $5.77 \pm 1.68^{\mathrm{b}}$ & $5.97 \pm 1.56^{\mathrm{a}}$ & $5.91 \pm 1.09^{\mathrm{b}}$ \\
Mn-W-S6-20s & & $6.05 \pm 1.82^{\mathrm{a}}$ & $5.69 \pm 2.25^{\mathrm{b}}$ & $6.12 \pm 1.32^{\mathrm{a}}$ & $5.97 \pm 1.96^{\mathrm{b}}$ \\
\hline
\end{tabular}

${ }^{1}$ : Mn-W: M. nitidum wines; S5: M. nitidum hydrolysate solution fermented by S. cerevisiae BCRC21686 (2.0\%) and BCRC21962 (2.0\%); S6: M. nitidum hydrolysate solution fermented by S. cerevisiae BCRC21824 (2.0\%) and BCRC21962 (2.0\%); 20s: the fermented wines of the $M$. nitidum hydrolysate solution with $20 \%$ sucrose added; $15^{\circ} \mathrm{C}$ aging: aging at $15^{\circ} \mathrm{C}$ for 3 month; $25^{\circ} \mathrm{C}$ aging: aging at $25^{\circ} \mathrm{C}$ for 3 month.

2: Grade: 1 = dislike extremely; 3 = dislike; $5=$ neither like nor dislike; $7=$ like; $9=$ like extremely.

3: Each value is the means \pm standard deviation $(\mathrm{n}=16)$. The different superscript letters in the same column are significantly different $(p<$ $0.05)$.

Hunter b values were $1.18-1.45$ and $1.46-1.66$, respectively. All the values decreased at $15^{\circ} \mathrm{C}(\mathrm{S} 5: 0.85-1.08$; S6: $1.01-1.22)$ and $25^{\circ} \mathrm{C}$ (S5: 0.75-0.92; S6: 0.85-1.09) after the aging period. The results from six $M$. nitidum wines fermented by the S5 and S6 yeast groups showed decreasing brightness, blueness, and greenness at two different temperatures, especially $25^{\circ} \mathrm{C}$. It is known that phenolic compounds contribute to wine color, taste, structure and make the product suitable for aging. Color is one of the main quality attributes of red wine and a matter of primary importance to winemakers [29]. The initial color of red wine is mainly due to free anthocyanins, self-association of anthocyanins, and co-pigmentation of anthocyanins with other phenols present in the wine. However, during wine aging, grape anthocyanins are gradually displaced by more stable oligomeric and polymeric pigments. The progress of many of these reactions is influenced by factors such as: temperature, oxygen access, $\mathrm{pH}$, acetaldehyde and free $\mathrm{SO}_{2}$ content [29].

\section{Sensory Evaluation}

Volatile compounds are important for beverage flavor as they contribute to different desirable sensory characteristics [5]. Table 7 shows the results of the sensory evaluations made by 8 males and 8 females, who were 23 years old on average, of $M$. nitidum wines with $10 \%-20 \%$ sucrose added, and on the color of M. nitidum wines fermented by S5 and S6 yeast groups, with no different statistical analysis. As for flavor, the M. nitidum wine fermented by the S6 yeast group was more acceptable than that of the S5 yeast group. No matter whether the $M$. nitidum wines were fermented by the S6 yeast groups with $20 \%$ sucrose, they had a better taste than those with $10 \%$ and $15 \%$ sucrose, with differences in statistical analysis. In regard to total preference, $M$. nitidum wine fermented by the S6 yeast groups with $20 \%$ sucrose received better evaluation than those with $10 \%$ and $15 \%$ sucrose, with differences in statistical analysis. Results of sensory evaluations by 11 males and 9 females, who were 22 years of age on average, of $M$. nitidum wines treated at different aging temperatures are displayed in Table 8. The color and taste of M. nitidum wines fermented by the $\mathrm{S} 5$ and $\mathrm{S} 6$ yeast groups at 15 or $25^{\circ} \mathrm{C}$ after 20 days showed no difference in statistical analysis. The flavor of and total preference for $M$. nitidum wines fermented by the S5 and $\mathrm{S} 6$ yeast groups at 15 or $25^{\circ} \mathrm{C}$ after 20 days showed no difference in statistical analysis. However there was a difference in statistical analysis among the two sets.

The aroma of a wine is one of the most important determinants of its quality. A wine may contain over 800 volatile compounds including alcohols, esters, organic acids, phenols, thiols, monoterpenes and norisoprenoids. The esters, alcohols and acetates are among the volatile compounds derived from 
yeast metabolism. The essence of a wine's flavor is formed during alcoholic fermentation. Ethanol and glycerol are the most abundant alcohols, followed by higher alcohols and esters, the combinations of which affect the final aroma of a wine [40]. Arrizon et al. [5] indicated that acetaldehyde is directly correlated with yeast metabolism in alcoholic fermentation because this compound is produced by decarboxylation of pyruvate, which is the direct product of glycolysis. Ethyl acetate is produced principally by the action of alcohol acetyl-transferase in S. cerevisiae. Conde et al. [11] further indicated that compared to other compounds, such as sugars and phenolics, the organoleptic effects of proteins on wine aroma can be considered negligible, but it has been shown that proteins can bind to volatile compounds, increasing the volatility of certain aromatic compounds (such as ethyl octanoate), and reducing it in other cases (such as ethyl hexanoate). Estévez et al. [14] studied the must obtained from Palomino grapes inoculated with seven different commercial yeast strains (three $S$. cerevisiae cerevisia: MO5, CEG and IOC BR 8000; and four S. cerevisiae bayanus: ALB, KD, REIMS and IOC 2007) and fermented under identical conditions. No differences were found in the gross chemical composition, but the wines had significantly different volatile characteristics and the results demonstrated that large sensory differences were generated by the different yeast strains that had been used in the vinification. The major constituents that contributed to the volatile composition in these wines were the higher alcohols, ethyl esters, acetates, fatty acids and volatile phenols. Vilanova et al. [39] also discovered that among Albariño wines that were fermented by 12 different yeast strains isolated from a single winery in Galicia, Spain, the chemical and sensorial properties of the wines differed depending on the yeast strains.

Xu et al. [47] studied the effect of $S$. cerevisiae only, and $S$. cerevisiae mixed with Hanseniaspora $(H$.$) valbyensis, on$ cider fermentation, involving alcoholic fermentation and the formation of flavor compounds. The concentration of major higher alcohols and esters in the cider differed depending on whether $S$. cerevisiae was added to the $H$. valbyensis fermentation on day 3,9 , or 15 . Compared to pure fermentation with $S$. cerevisiae, mixed fermentation resulted in abvious increase in the total concentration of esters of $7.41 \%$ to $20.96 \%$, and a decrease in the total concentration of alcohols of $25.06 \%$ to $51.38 \%$. The major contributors to variations in total esters were ethyl acetate and phenethyl acetate, which are considered to be the main impact aroma compounds in cider, and those for the alcohols were isoamyl alcohol and isobutyl alcohol. These studies have demonstrated that fermentation conditions and aging affect the final aromatic composition, and then affect the wines sensory value. Moreno and Azpilicueta [30] indicated that during maturation, wine aroma becomes more complex and the color becomes more stable. In wine aging, esters are mainly formed during fermentation by enzymatic conversions. The concentrations attained by esters at the end of fermentation depend on the temperature, the yeast strain that pre- dominates in the fermentation and the nutrients in the medium, especially with concentration of nitrogen compounds and must solids. In maturing wine, esters may be degraded or synthesized through chemical esterification, or remain at constant concentrations. The acetate esters of higher alcohols generally degraded more rapidly than the ethyl esters of fatty acids in both white wine and model solutions. The rate of hydrolysis of fatty acid esters varied in proportion to their molecular weight. Consequently, a rapid degradation of heavy esters was observed. Although the preference for all groups of $M$. nitidum wine after 20 days aging at 15 or $25^{\circ} \mathrm{C}$ were lower than 7. The acceptances of these wines were still high. The $M$. nitidum wines in this present study possess further value for wine manufacturing.

\section{ACKNOWLEDGMENTS}

The authors are grateful to the Fisheries Agency, Council of Agriculture, Executive Yuan, R.O.C., for its support of this work (Grant No. 94 AS-12.1.3-FA-F1-03).

\section{REFERENCES}

1. Abe, S. and Kaneda, T., "Studies on the effect of marine products on cholesterol metabolism in rats - viii. The isolation of hypocholesterolemic substance from green laver," Bulletin of the Japanese Society of Scientific Fisheries, Vol. 39, pp. 383-389 (1973a).

2. Abe, S. and Kaneda, T., "Studies on the effect of marine products on cholesterol metabolism in rats - xi. Effect of betains on plasma and liver cholesterol levels," Bulletin of the Japanese Society of Scientific Fisheries, Vol. 39, pp. 391-393 (1973b).

3. Amerine, M. A. and Ough, C. S., Method for Analysis of Musts and Wines, Willey-Interscience Publication, New York, U.S.A. (1980)

4. AOAC, Official Methods of Analysis of AOAC International, Edited by Cunniff, P., 16th ed., AOAC International, Gaithersburg, MD (1997).

5. Arrizon, J., Calderón, C., and Sandoval, G., "Effect of different fermentation conditions on the kinetic parameters and production of volatile compounds during the elaboration of a prickly pear distilled beverage," Journal of Industrial Microbiology and Biotechnology, Vol. 33, pp. 921928 (2006).

6. Asano, T., Kurose, N., and Tarumi, S., "Isolation of high-malateproducing sake yeasts from low-maltose-assimilating mutants," Journal of Bioscience and Bioengineering, Vol. 92, pp. 429-433 (2001).

7. Billmeyer, F. W., "Current status of the color-difference problem," Journal of Coating Technology, Vol. 51, pp. $46-47$ (1979).

8. Charles, A. L., Chang, C.-K., Wu, M.-L., and Huang, T.-C., "Studies on the expression of liver detoxifying enzymes in rats fed seaweed (Monostroma nitidum)," Food and Chemical Toxicology, Vol. 45, pp. 2390-2396 (2007).

9. Chen, R.-H. and Chen, W.-Y., "Skin hydration effects, film formation time, and physicochemical properties of a moisture mask containing Monostroma nitidium water-soluble mucilage," Journal of Cosmetic Science, Vol. 54, pp. 9-20 (2003).

10. Chiang, L.-C., Gong, C.-S., Chen, L.-F., and Tsao, G.-T., "D-xylulose fermentation to ethanol by Saccharomyces cerevisiae," Applied and Environmental Microbiology, Vol. 42, pp. 284-289 (1981).

11. Conde, C., Silva, P., Fontes, N., Dias, A. C. P., Tavares, R. M., Sousa, M. J., Agasse, A., Delrot, S., and Gerós, H., "Biochemical changes throughout grape berry development and fruit and wine quality," Food, Vol. 1, pp. 1-22 (2007).

12. D'Amore, T., Panchal, C. J., and Stewart, G. G., "Intracellular ethanol accumulation in Saccharomyces cerevisiae during fermentation," Applied 
and Environmental Microbiology, Vol. 54, pp. 110-114 (1988).

13. Dubois, M., Gilles, K. A., Hamilton, J. K., Rebers, P. A., and Smith, F., "Colormertric method for determination of sugars and related substances," Analytical Chemistry, Vol. 28, pp. 350-356 (1956).

14. Estévez, P., Gil, M. L., and Falqué, E., "Effects of seven yeast strains on the volatile composition of Palomino wines," International Journal of Food Sciences and Technology, Vol. 39, pp. 61-69 (2004).

15. FDA, Food and Drug Administration, Bacteriological Analytical Manual, 7th ed., AOAC, Arlington, U.S.A. (1992).

16. Guillaume, C., Delobel, P., Sablayrolles, J.-M., and Blondin, B., "Molecular basis of fructose utilization by the wine yeast Saccharomyces cerevisiae: A mutated HXT3 allele enhances fructose fermentation," Applied and Environmental Microbiology, Vol. 73, pp. 2432-2439 (2007)

17. Harada, N. and Maeda, M., "Chemical structure of antithrombin-active rhamnan sulfate from Monostrom nitidum," Bioscience, Biotechnology, and Biochemistry, Vol. 62, pp. 1647-1652 (1998).

18. Houghton-Larsen, J. and Brandt, A., "Fermentation of high concentrations of maltose by Saccharomyces cerevisiae is limited by the compass methylation complex," Applied and Environmental Microbiology, Vol. 72 , pp. 7176-7182 (2006).

19. Jansen, M. L. A., Daran-Lapujade, P., de Winde, J. H., Piper, M. D. W., and Pronk, J. T., "Prolonged maltose-limited cultivation of Saccharomyces cerevisiae selects for cells with improved maltose affinity and hypersensitivity," Applied and Environmental Microbiology, Vol. 70, pp. 1956-1963 (2004).

20. Jones, H. L., Margaritis, A., and Stewart, R. J., "The combined effects of oxygen supply strategy, inoculum size and temperature profile on very high-gravity beer fermentation by Saccharomyces cerevisiae," Journal of the Institute of Brewing, Vol. 113, pp. 168-184 (2007).

21. Kofli, N. T., Nagahisa, K., Shimizu, H., and Shioya, S., "Responses of different strains of Saccharomyces cerevisiae," Sains Malaysiana, Vol. 35, pp. 9-15 (2006).

22. Kültz, D. and Burg, M., "Evolution of osmotic stress signaling via map kinase cascades," The Journal of Experimental Biology, Vol. 201, pp 3015-3021 (1998).

23. Lee, J. B., Hayashi, K., Maeda, M., and Hayashi, T., "Antiherpetic activities of sulfated polysaccharides from green algae," Planta Medica, Vol. 70, pp. 813-817 (2004).

24. Lekkas, C., Stewart, G. G., Hill, A. E., Taidi, B., and Hodgson, J., "Elucidation of the role of nitrogenous wort components in yeast fermentation," Journal of the Institute of Brewing, Vol. 113, pp. 3-8 (2007)

25. Maeda, M., Uehara, T., Harada, N., Sekiguchi, M., and Hiraoka, A., "Heparinoid-active sulfated polysaccharides from Monostroma nitidum and their distribution in the Chlorophyta," Phytochemistry, Vol. 30, pp. 3611-3614 (1991).

26. Maeshige, S., "Chemical studies on the green alga, Monostroma nitidum wittrock-I. Component sugars of the mucilage (part 1)," Bulletin of the Japanese Society of Scientific Fisheries, Vol. 28, pp. 326-334 (1962).

27. Malacrinò, P., Tosi, E., Caramia, G., Prisco, R., and Zapparoli, G., "The vinification of partially dried grapes: A comparative fermentation study of Saccharomyces cerevisiae strains under high sugar stress," Letters in Applied Microbiology, Vol. 40, pp. 466-472 (2005).

28. Miller, G. L., Dean, J., and Blum, R., “A study of methods for preparing oligosaccharides from cellulose," Archives of Biochemistry and Biophysics, Vol. 91, pp. 21-26 (1959).

29. Monagas, M., Martín-Álvarez, P. J., Gómez-Cordovés, C., and Bartolomé, B., "Time course of the colour of young red wines from Vitis vinifera L. during ageing in bottle," International Journal of Food Sciences and Technology, Vol. 41, pp. 892-899 (2006).

30. Moreno, N. J. and Azpilicueta, C. A., "The development of esters in filtered and unfiltered wines that have been aged in oak barrels," International Journal of Food Sciences and Technology, Vol. 41, pp. 155-161 (2006)

31. Morita, Y., Nakamori, S., and Takagi, H., "Effect of proline and arginine metabolism on freezing stress of Saccharomyces cerevisiae," Journal of Bioscience and Bioengineering, Vol. 94, pp. 390-394 (2002).

32. Okunowo, W. O. and Osuntoki, A. A., "Quantitation of alcohols in orange wine fermented by four strains of yeast," African Journal of Biochemical Research, Vol. 1, pp. 95-100 (2007)

33. Phowchinda, O. and Strehaiano, P., "Utilization of mixed sugars for alcoholic fermentation by $S$. cerevisiae," Thammasat International Journal of Science and Technology, Vol. 4, pp. 23-31 (1999).

34. Reddy, L. V. A. and Reddy, O. V. S., "Improvement of ethanol production in very high gravity fermentation by horse gram (Dolichos biflorus) flour supplementation," Letters in Applied Microbiolog, Vol. 41, pp. 440-444 (2005).

35. Rogerson, F. and Symington, C., "A method for the estimation of alcohol in fortified wines using hydrometer baumé and refractometer brix," American Journal of Enology and Viticulture, Vol. 57, pp. 486-490 (2006).

36. SAS Institution, User's Guide, Release 8.0 ed., SAS Institution, Cary, N.C. (1997).

37. Sritrakul, N., Laopaiboon, P., Danvirutai, P., and Laopaiboon, L., "Continuous mango wine fermentation in a packed-bed bioreactor using immobilized yeasts: System stability and volatile by-products," Thailand Journal of Biotechnology, Vol. 8, pp. 5-10 (2007).

38. Takagi, H., Takaoka, M., Kawaguchi, A., and Kubo, Y., "Effect of L-proline on sake brewing and ethanol stress in Saccharomyces cerevisiae," Applied and Environmental Microbiolog, Vol. 71, pp. 8656-8662 (2005).

39. Vilanova, M., Masneuf-Pomarède, I., and Dubourdieu, D., "Influence of Saccharomyces cerevisiae strains on general composition and sensorial properties of white wines made from vitis vinifera cv. Albariño," Food Technology and Biotechnology, Vol. 43, pp. $79-83$ (2005).

40. Vilanova, M. and Sieiro, C., "Contribution by Saccharomyces cerevisiae yeast to fermentative flavour compounds in wines from cv. Albariño," Journal of Industrial Microbiology and Biotechnology, Vol. 33, pp. 929933 (2006).

41. Vriesekoop, F. and Pamment, N. B., "Acetaldehyde addition and preadaptation to the stressor together virtually eliminate the ethanol-induced lag phase in Saccharomyces cerevisiae," Letters in Applied Microbiolog, Vol. 41, pp. 424-427 (2005).

42. Willaert, R. and Nedovic, V. A., "Primary beer fermentation by immobilized yeast - a review on flavour formation and control strategies," Journal of Chemical Technology and Biotechnology, Vol. 81, pp. 1353 1367 (2006).

43. Wu, S.-C. and Pan, C.-L., "Preparation of algal-oligosaccharide mixtures by bacterial agarases and their antioxidative properties," Fisheries Science, Vol. 70, pp. 1164-1173 (2004).

44. Wu, S.-C., Wang, F.-J., and Pan, C.-L., "Growth and survival of Streptococcus faecalis and Lactobacillus rhamnosus during agar oligosaccharides fermentation and storage," Journal of the Fisheries Society of Taiwan, Vol. 32, pp. 239-251 (2005a).

45. Wu, S.-C., Wang, F.-J., and Pan, C.-L., "Growth and survival of lactic acid bacteria during the fermentation and storage of seaweed oligosaccharides solution," Journal of Marine Science and Technology, Vol. 15, pp. 104-114 (2007).

46. Wu, S.-C., Wen, T.-N., and Pan, C.-L., "The antioxidative properties of algal-oligosaccharide-lysates hydrolyzed by two bacterial agarases," Fisheries Science, Vol. 71, pp. 1149-1159 (2005b).

47. Xu, Y., Zhao, G.-A., and Wang, L.-P., "Controlled formation of volatile components in cider making using a combination of Saccharomyces cerevisiae and Hanseniaspora valbyensis yeast species," Journal of Industrial Microbiology and Biotechnology, Vol. 33, pp. 192-196 (2006).

48. Zhang, H.-J., Mao, W.-J., Fang, F., Li, H.-Y., Sun, H.-H., Chen, Y., and Qi, X.-H., "Chemical characteristics and anticoagulant activities of a sulfated polysaccharide and its fragments from Monostroma latissimum," Carbohydrate Polymers, Vol. 71, pp. 428-434 (2008). 